\title{
Ecodiagrams of common species of the forest herb layer in the Roztocze National Park
}

\author{
BOŻENNA CZARNECKA
}

Department of Ecology, Institute of Biology, M. Curie-Skłodowska University, Akademicka 19. 20-033 Lublin, Poland

(Received: April 26. 1985. Accepted: September 26, 1985)

\begin{abstract}
The paper presents in graphic standardised form ("ecodiagrams") the conditions in which 24 common species of the herb layer of forest communities occur in the Roztocze National Park. After determining the soil type, its mechanical composition, active and exchangeable acidity, humus content and the content in the rhizosphere layer of nutrient components essential for plants, such as $\mathrm{P}, \mathrm{K}, \mathrm{Na}, \mathrm{Ca}, \mathrm{Mg}, \mathrm{Al}$, ammonium nitrogen and nitrate nitrogen, the habitats of common plants of the forest from the class Querco-Fagetea were classified as meso-, eu-meso- and cutrophic. Forest plants connected with communities from the class Vaccinio-Piceetea (Hieracium lachenalii Gmel., Melampyrum pratense L., Trientalis europaea L., Vaccinium myrtillus L.) are generally associated with fresh, moderately poor and quite frequently also mesotrophic soils. Only Vaccinium vitis-idaea L. is a local species of dry hungry soils, poor in mineral and organic components. The group of accompanying species such as Fragaria vesca L., Galium vernum Scop., Luzula pilosa (L.) Willd., Mycelis ruralis (L.) Dum. and Oxalis acetosella L., show a much wider ecological amplitude - from oligotrophic to eutrophic habitats.
\end{abstract}

Key words: ecodiagrams, ecological amplitude, herb layer, edaphic factors

\section{INTRODUCTION}

In ecological research more and more space is lately assigned to autecology. Investigations on the biology of species and the reaction of their populations to different habitat conditions usually concern several ecosystems, hence they contain but little information on the ecological species in reference to edaphic, orographic or climatic conditions.

Zarzycki (1976a, b) was the first in the Polish literature to try and present in standardised graphic form data concerning the conditions of occurrence of several score forest, meadow and epilithic vascular plants of the Pieniny Mts. He gave in "ecodiagrams" much information on the 
distribution of the sites of the given species in dependence on the altitude above sea level, exposure of the slopes, soil type, its acidity and moisture, with supplementary data on the frequency and mean coverage by the species in plant communities. Zarzycki (1976b) postulated, moreover. the taking into account in studies on the ecology of species of such factors influencing the distribution of plants in nature as the nitrogen forms and readily assimilable phosphorus. Among numerous ecological factors conditioning the appearance of plants, most prominent are edaphic factors on account of the strong interaction between plants and the soil and the great complexity and dynamics of the latter (Musierowicz and Uggla 1964. Daubenmire 1973. Obmiński 1978 and Richards 1979).

The aim of the present paper is to present the reaction of common forest herb layer species to the environmental and habitat conditions. especially to the edaphic ones, prevailing in forest communities of the Roztocze National Park. In investigations on the ecological amplitude of species the suggestions of Zarzycki (1976b) concerning the forms of nitrogen and available phosphorus were taken into account. At the same time the scope of the analysed factors was extended to determination of the contents in the forest community soils of other macro- and microelements essential for plants $(\mathrm{Ca}, \mathrm{Mg}, \mathrm{K}, \mathrm{Na}, \mathrm{Fe}, \mathrm{Al})$.

INVESTIGATED AREA

The materials for the ecodiagrams of the chosen species of the forest herb layer were taken from the Roztocze National Park (Izdebski and Filałkowski 1978) and several neighbouring forest sections. The Park (Fig. 1) lies within the Central Roztocze which was distinguished on the basis of its morphology. geological structure and floristic differentiation as one of the three areas of the Roztocze region belonging to the belt of Central Polish Uplands (Chałubińska and Wilgat 1959).

The territory studied has a rather diversified relief; elevation above sea level within the boundaries of the Park reaches $364 \mathrm{~m}$ and relative height $60 \mathrm{~m}$. In the geological structure cretaceous formations dominate in the form of gaizes and marls forming upland planations. Extensive depressions of the territory and river valleys are filled with quaternary sands and peat. Small patches of boulder clay may be also found here and loess more common than the latter (Izdebski 1961. K limaszewsk i 1972).

The elevation above the surrounding area finds its reflection in the climatic features of Roztocze which belongs to the group of climates of the Central Uplands (Michna and Warakomski 1967/1968), where oceanic and continental influences collide, with the prevalence, however. 


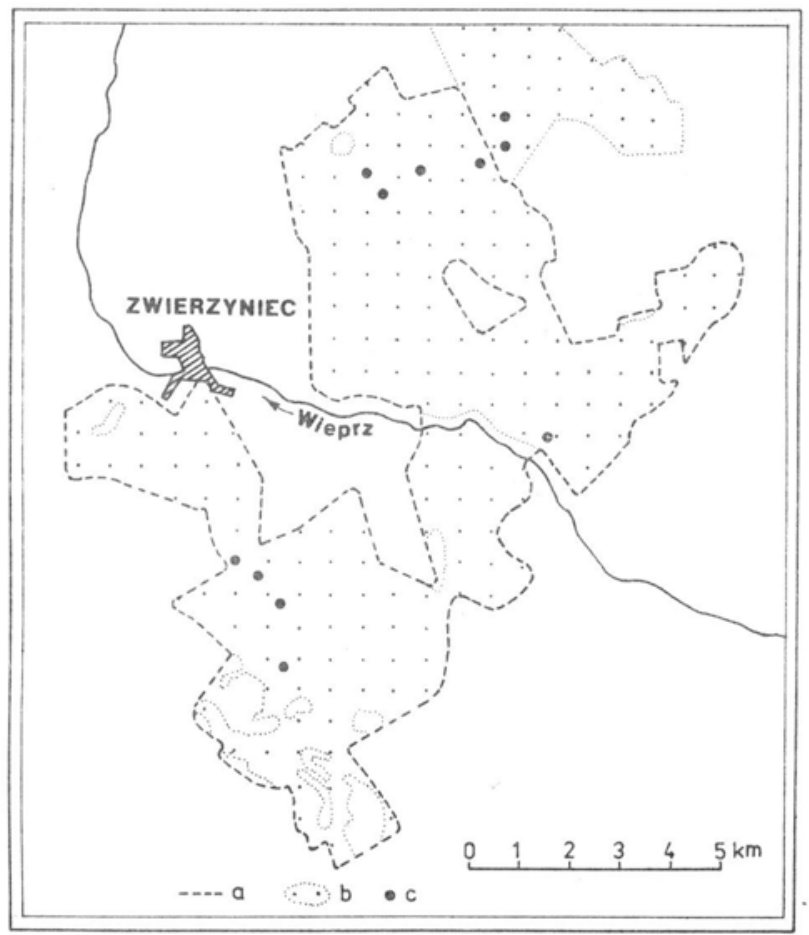

Fig. I. Situational map of the study area; a-boundaries of the Roztocze National Park. b-forest areas c-sites where the transects were taken

of the latter. The increase of continentality is seen in an increased temperature amplitude between summer and winter and the appearance of cold air draining areas due to thermic contrasts. The winter and summer are here rather long (more than 100 days), whereas the transition periods are short. The coldest month is January and the warmest July, the annual temperature minimum, however, falls to February and the maximum to August. The lowest relative air moisture values are noted in May, the highest in December. The sky overcast is similar to the country-wide minimum, insolation, on the contrary, reaches the highest values in Poland. The vegetation period is about 205 days.

Roztocze receives more precipitation than the surrounding regions (more than $700 \mathrm{~mm}$ annually) however, owing to its geological structure (high permeability of the substrate) surface waters are scarse here, and the ground water level is low, valleys filled with peat excepted.

The main river flowing through the Roztocze National Park is the Wieprz. The Park extends on both sides of its upper course close to the confluence with the small stream Świerszcz which supplies a complex of ponds "Echo" with its waters. 
In dependence on the terrain relief, the character of the bed rock, water relations, and type of plant communities, various soils have developed: peat soils, brown soils, creataceous rendzinas and podsolic soils extending over the greater part of the Park (Izdebski 1961).

A characteristic in detail of the extremely rich and diversified floristic, phytosociological and habitat conditions of Central Roztocze including the National Park are given in numerous studies (Izdebski 1959, 1961, 1962a, b, 1963, 1964, 1972, Izdebska 1960, Izdebska and Szynal 1961, Szynal 1962. Izdebski and Popiołek 1969. 1975. 1976. Kimsa 1974. Czarnecka 1978 and others).

\section{MATERIALS AND METHODS}

Field investigations were conducted in full vegetation season (June/July) 1979, along a dozen or so transects running through the most important forest communities of the Park, both those in least modified form and those bearing the brunt of severe anthropogenic transformations. Lists of herb layer vegetation have been prepared within 305 sampling squares of $1 \mathrm{~m}^{2}$ each. Coverage by species is given in a 10-grade scale. Moreover. for all sampling squares the height a.s.l., slope, general and local exposure and type of community have been determined. At the same time mixed soil samples were collected (from 5 points on each square) from the rhizosphere (at a depth of $2-15 \mathrm{~cm}$ ) and subjected to analysis. In these samples some physico-chemical properties of the forest soils were routinely determined (Dobrzański and Uziak 1970, "Metody..." 1967), their mechanical composition by the areometric method of Casagrande in Prószyński's modification, active acidity $\left(\mathrm{pH}\right.$ in dist. $\mathrm{H}_{2} \mathrm{O}$ ) and exchangeable acidity $(\mathrm{pH}$ in $1 \mathrm{~N} \mathrm{KCl})$ by the electrometric method by means of an "Orion" $\mathrm{pH}$-metre, humus content (in mineral soils) by Tiurin's method and organic matter content (in organic soils) by the method of incandescence in a muffle. phosphorus (with addition of photo-rex), magnesium (with titanium yellow), iron (with o-phenanthroline) and aluminium (with thioglycolic acid) by the colorimetric method in a Spekol type apparatus, potassium, sodium and calcium by means of a flame photometre, nitrogen in ammonium form by Kjeldahl's method and in nitrate form (with brucine added) by the colorimetric method.

The term "organic soils" refers in this paper jointly to peat soils formed of low peat, transitional and high peats and muck-mineral or peaty-mineral soils.

Information collected on the surface of 305 sampling squares and obtained from analyses of the soil material from the same sampling sites were 
supplemented by the results of a dozen or so above quoted synecological elaborations. Four hundred phytosociological records were analysed from the point of view of altitude a.s.l., exposure, type of community, frequency of species and degree of coverage by them in the given community. Numerous descriptions of soil pits and tables illustrating the physical and chemical properties of the forest soils supplied additional information on the type of soil, mechanical composition within the rhizosphere, acidity, humus and organic matter contents and richness in phosphorus and potassium.

The conditions of occurrence of 24 common herb layer species are shown in the form of ecodiagrams (Figs. 2-25): 14 species connected with forest communities from the class Querco-Fagetea, 5 species characteristic for forest communities from the class Vaccinio-Piceetea and 5 accompanying ones (Szafer and Zarzycki 1972, Matuszkiewicz 1981). The species are listed alphabetically in the groups. The specific names of plants are given after Szafer et al. (1969), the communities in the ecodiagrams are arranged according to Matuszkiewicz (1981).

In the presentation of results of field and laboratory investigations ecodiagrams were not prepared illustrating the vertical distribution of species and their sites in dependence on the exposure. These factors, as results from the author's observations and bibliographic data, are of no major consequence for the Roztocze National Park area on account of the little absolute and relative altitudes and lack of a closer connection with the exposure of the slopes in the case of the forest communities as well as the particular plant species growing in them.

In the successive ecodiagrams the results of investigations on the transects and data from synecological elaborations obtained sometimes by other methods and for other purposes are treated separately.

\section{RESULTS}

It results from analysis of the ecodiagrams that the species of deciduous forest from the class Querco-Fagetea plants are present in most forest communities of the Roztocze National Park. They are, however, usually associated with phytocenoses belonging to the communities of the class Querco-Fagetea. They attain the highest frequency and degree of coverage in general in the Dentario glandulosae-Fagetum association in its typical form and degraded forms of beech forest, in pine forest in an oak-hornbeam and beech forest habitats (Figs. 2 A,B-15 A,B) and also in fragments of Tilio-Carpinetum and communities with a considerable participation of Carpinus betulus in the stands. They are also regular components of the herb layer in the association Abietetum polonicum and fir communities 


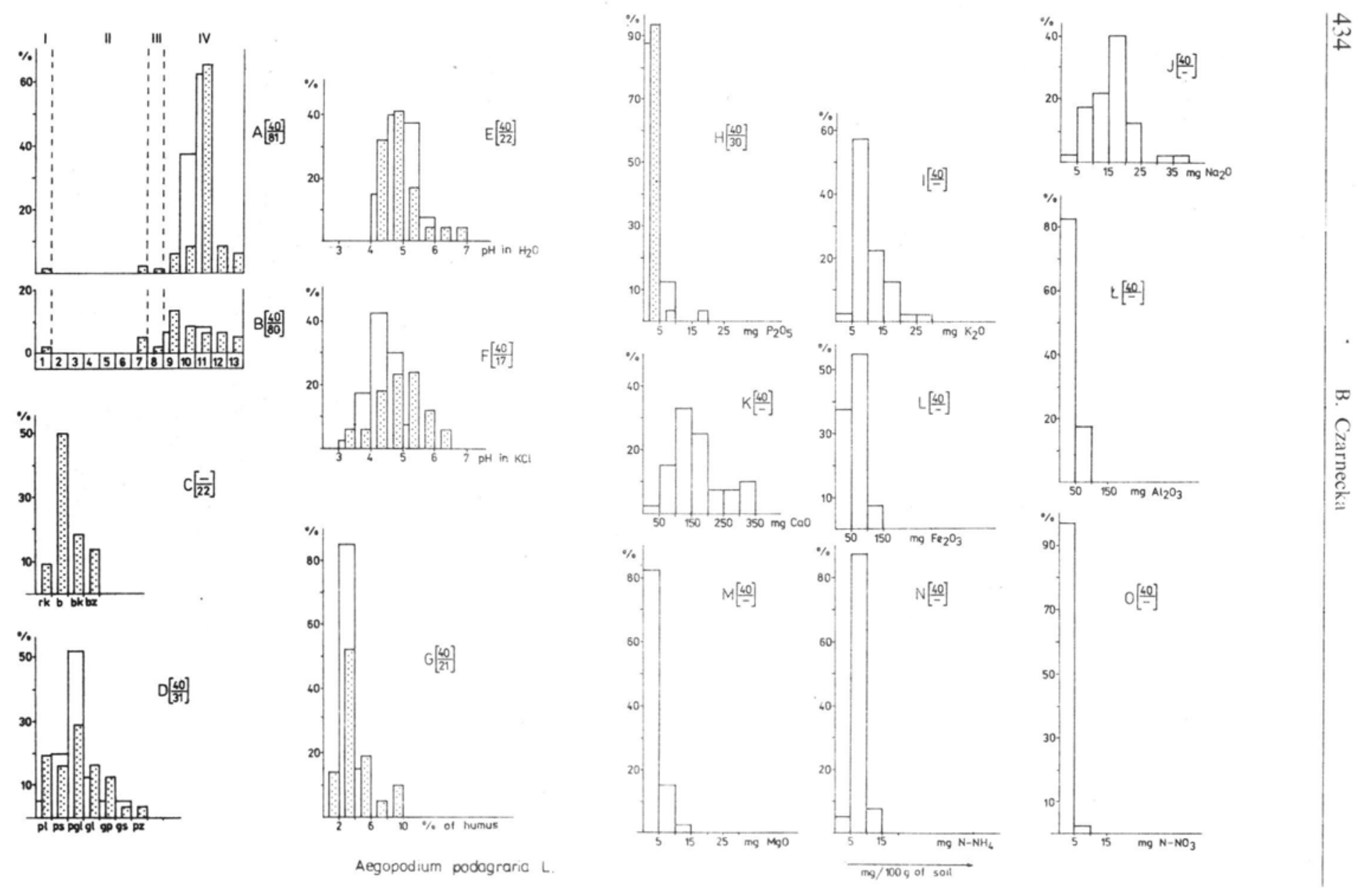


of the class Querco-Fagetea and Potentillo albae-Quercetum, although in this association some species do not attain a larger coverage. The majority of the studied species (Milium effusum and Sanicula europaea excepted) are found in a smaller coverage also in the association Fago-Quercetum petraeae. Some of these plants are sometimes a component of the herb layer of mixed coniferous forests, as Quercoroboris-Pinetum and Querco-Piceetum, of alder forest (Carci elongatae-Alnetum) and of forest communities with a high participation of Carex bryzoides. None of the species connected

Fig. 2. Ecodiagrams of Aegopodium podagraria L.; A - frequency of the species in forest communities. B average coverage of the species in communities, C distribution of sites of the species on various types of soil, D-distribution of sites of the species according to the mechanical composition of soil from the rhizosphere, E-distribution of sites of species according to the active soil acidity $\left(\mathrm{pH}\right.$ in $\mathrm{H}_{2} \mathrm{O}$ dist.), $\mathrm{F}$ - distribution of sites of the species according to the exchangeable soil acidity $(\mathrm{pH}$ in $1 \mathrm{~N} \mathrm{KCl}), \mathrm{G}$ - distribution of sites of the species according to percentage of humus or organic matter (org), $\mathrm{H}-$ distribution of sites of the species according to available phosphorus content (in $\mathrm{mg} \mathrm{P}_{2} \mathrm{O}_{5}$ per $100 \mathrm{~g}$ of soil), I - distribution of sites of the species according to accesible potassium content (in $\mathrm{mg} \mathrm{K}_{2} \mathrm{O}$ per $100 \mathrm{~g}$ of soil), $\mathbf{J}$-distribution of sites of the species according to sodium content (in $\mathrm{mg} \mathrm{Na} \mathrm{Na}_{2} \mathrm{O}$ per $100 \mathrm{~g}$ of soil), $\mathrm{K}$ - distribution of sites of the species according to calcium content (in $\mathrm{mg} \mathrm{CaO}$ per $100 \mathrm{~g}$ of soil), $\mathrm{L}$ - distribution of sites of the species according to iron content (in $\mathrm{mg} \mathrm{Fe}_{2} \mathrm{O}_{3}$ per $100 \mathrm{~g}$ of soil), $\mathrm{-} \mathrm{-} \mathrm{distribution}$ of sites of the species according to aluminium content (in $\mathrm{mg} \mathrm{Al}_{2} \mathrm{O}_{3}$ per $100 \mathrm{~g}$ of soil), $\mathrm{M}$ - distribution of sites of the species according to magnesium content (in $\mathrm{mg} \mathrm{MgO}$ per $100 \mathrm{~g}$ of soil), $\mathrm{N}$-distribution of sites of the species according to ammonium nitrogen content (in $\mathrm{mg} \mathrm{N}-\mathrm{NH}_{4}$ per $100 \mathrm{~g}$ of soil), $\mathrm{O}$ - distribution of sites of the species according to nitrate nitrogen content (in $\mathrm{N}^{-\mathrm{NO}_{3}}$ per $100 \mathrm{~g}$ of soil); $\mathrm{I}$-communities of the class Alnetea glutinosae. II - communities of the class Vaccinio-Piceetea, III - communities of the class Quercetea roboris-Petraeae, IV - communities of the class Querco-Fagetea; 1 -Carici elongatae-Alnetum, 2 - Querco roboris-Pinetum, 3-Querco-Piceetum, 4-forest community with Carex bryzoides, 5-Vaccinio uliginosi-Pinetum, 6-Leucobryo-Pinetum, 7 - Abietetum polonicum, 8 - Fago-Quercetum petraeae, 9 - Potentillo albae-Quercetum, 10 - Tilio-Carpinetum and communities of the order Fagetalia with a predominance of Carpinus betulus, 11 Dentario glandulosae-Fagetum, 12 -impoverished form of Carpathian beechwoot and communities of the order Fagetalia with pine, 13 - fir communities of the class Querco-Fagetea; rk - cretaceous rendzina, b- brown soil formed of cretaceous rocks, bk - acid brown soil, bz - brown podsolic soil, bl - brown soil formed of loess and loess formations, p-podsolic soil formed of loose sandy and coarse sandy soils, pg - podsolic soil formed of medium sands and loams, $\mathrm{t}$-peat soil formed of lowmoor or transitional moor, tm - mineral-peaty soil, $\mathrm{m}$ - mineral-muck soil, pl - loose sandy soil, ps - coarse sandy soil, pgl - medium sand, gl - sandy loam, gp - very-fine sandy loam; gś - medium-heavy loam, gc - heavy loam, pz - very-fine sandy soil, o-organic soils group. Numbers in brackets: numerator-- number of observations or measurements from own investigations (empty columns), denominator -number of observations or measurements from synecological 
with forest communities from the class Querco-Fagetea were, however, found in typical pinewood communities such as Vaccinio uliginosi-Pinetum and Leucobryo-Pinetum.

Only Aegopodium podagraria (Fig. 4 C, D), Galeobdolon luteum (Fig. 8 C, D), Pulmonaria obscura (Fig. 13 C, D), Sanicula europaea (Fig. 14 C, D) and Stellaria holostea (Fig. 15 C, D) were distinctly bound with a definite kind of soil and its mechanical composition within the rhizosphere layer. At least half of the sites of the above mentioned species grow on brown soils formed of rock of cretaceous formations with a mechanical composition of medium sands and loams.

Most of the deciduous forest species were recorded on soils of active acidity within the limits of 4.0-5.5 and exchangeable acidity 3.5-5.0 pH units (Figs. 2 E, F-15 E, F). Thus, these are highly acidic to lightly acidic soils. It is only rarely that soil $\mathrm{pH}$ is close to neutral within the rhizosphere.

Humus content in the soils occupied by the discussed species varies within rather wide limits - from 0 to 10 per cent of humic compounds. Most frequently, however, this content lies within 2-6 per cent (Figs. 2G-15G). A dozen or so per cent of Geranium robertianum sites (Fig. 9G) and as many as 40 per cent of Milium effusum sites (Fig. 12G) occupy soils with a high organic matter content in the level where they are rooted.

The soils with which the studied species were mostly associated mostly contain only trace amounts of easily assimilable phosphorus (Figs. 2H-15H). In the samples analysed $\mathrm{P}_{2} \mathrm{O}_{5}$ content did not exceed $20 \mathrm{mg}$ per $100 \mathrm{~g}$ soil. The soils were somewhat richer in assimilable potassium (Figs. 2I-15I). Most sites of all the deciduous forest species lie within the limits of soil with 5-15 $\mathrm{mg} \mathrm{K}_{2} \mathrm{O}$ per $100 \mathrm{~g}$ soil. Maximal content of this component only exceptionally exceeds $40 \mathrm{mg}$ per $100 \mathrm{~g}$ soil (Figs. 3I, 7I, 8I, 11I). Similar proportions are noted in the sites as regards sodium content within the rhizosphere (Figs. 2J-15J).

The calcium content varies within rather wide limits - from 0 to more than $300 \mathrm{mg} \mathrm{CaO}$ per $100 \mathrm{~g}$ soil. The distribution of frequency classes is more or less uniform for most plants (Figs. 2K-15K). Only Circaea alpina (Fig. 7K), Geranium robertianum (Fig. 9K) and Milium effusum (Fig. 12K) in 30-50 per cent of cases grow on soils with a calcium content above $300 \mathrm{mg}$ per $100 \mathrm{~g}$ soil.

The upper layer of most soils has a negligible iron content (Figs. 2L-15L). In the distribution of sites with Circaea alpina (Fig. 7L) and Geranium robertianum (Fig. 9L) noteworthy is the class with $200-250 \mathrm{mg} \mathrm{Fe}_{2} \mathrm{O}_{3}$ per $100 \mathrm{~g}$ soil to which falls a dozen or so per cent of both these species. As regards Milium effusum (Fig. 13L) as many as 50 per cent sites belong to the class with $\mathrm{Fe}_{2} \mathrm{O}_{3}$ content within the limits of $100-150 \mathrm{mg}$ per $100 \mathrm{~g}$ soil. 


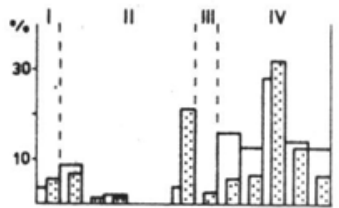

20ㄴ
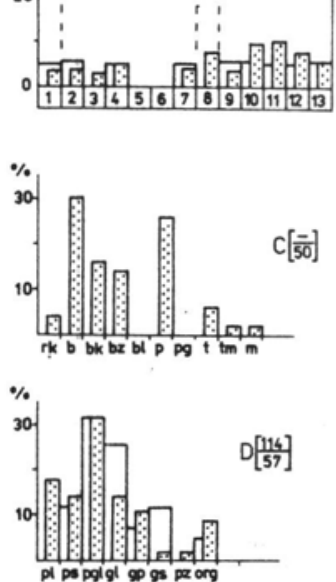

\section{$A[1116]$}

$8\left[\frac{114}{147}\right]$
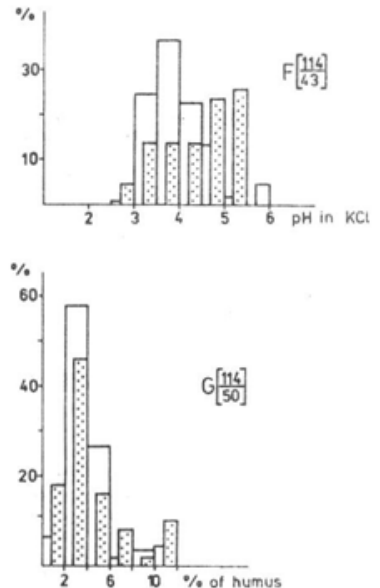

Anemone nemorosa $L$
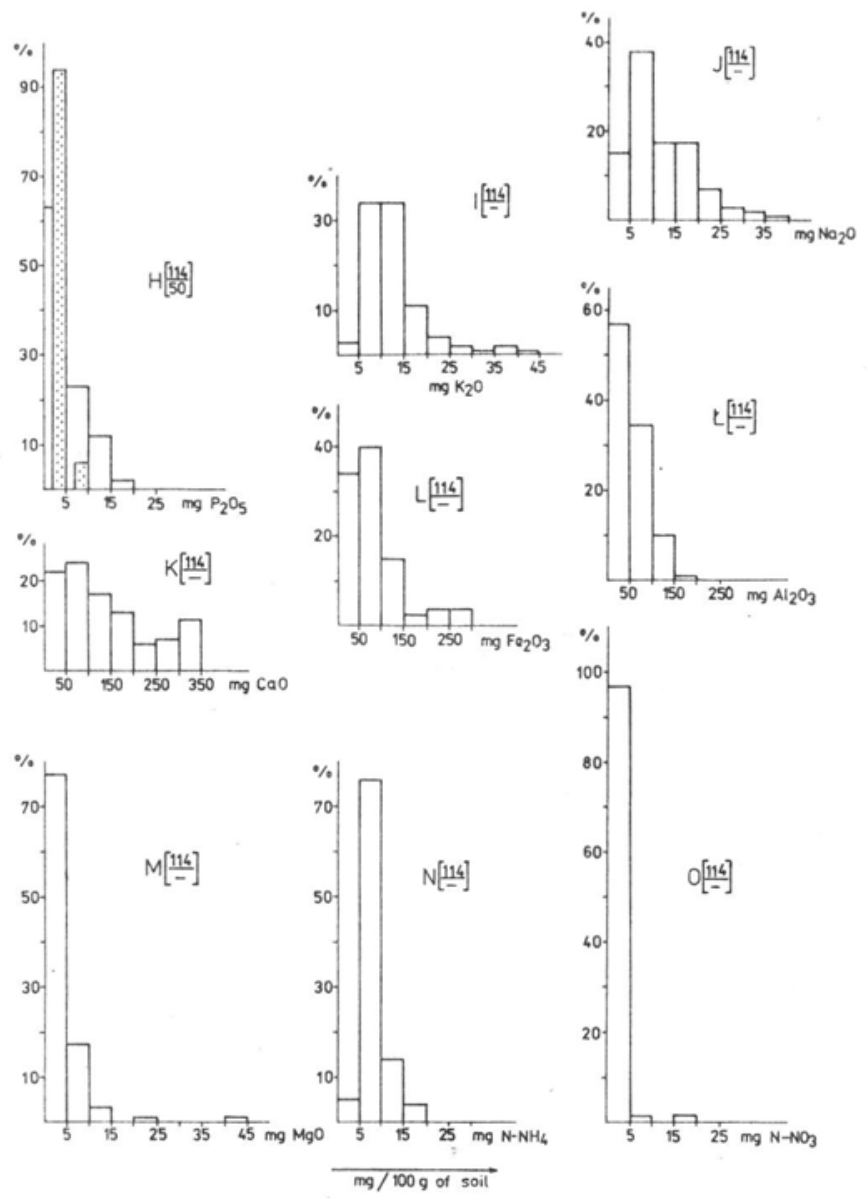

Fig. 3. Ecodiagrams of Anemone nemorosa L. (explanations as in Fig. 2) 

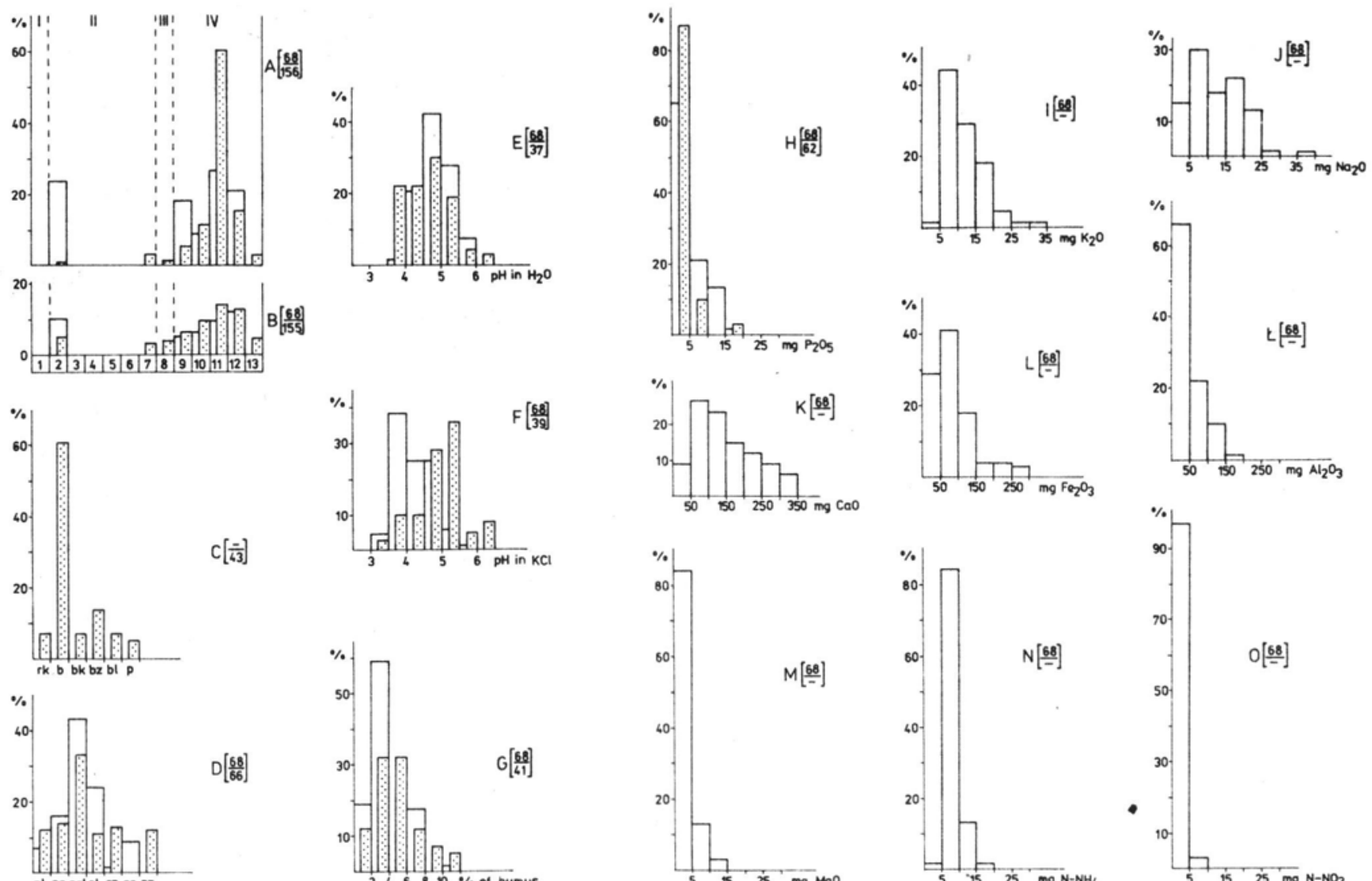

$c[\overline{\overline{3}}]$
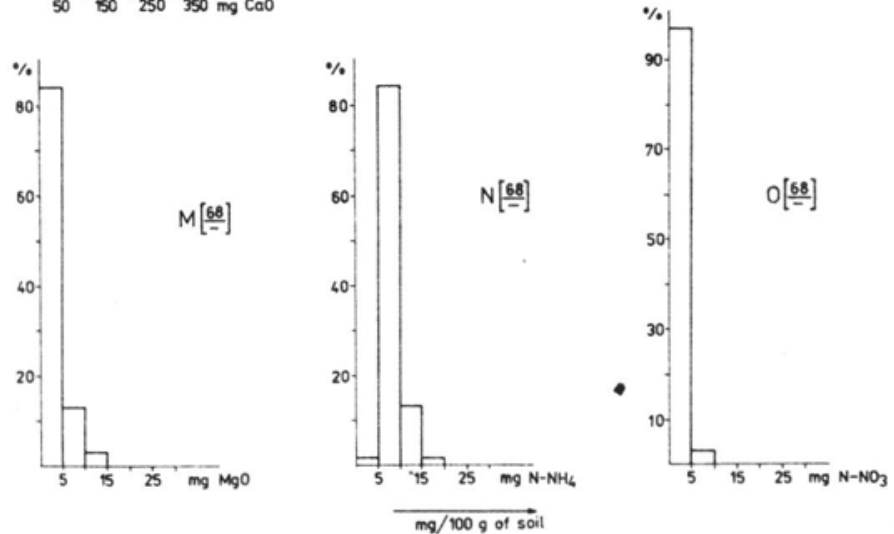

Asarum europaeum L.

Fig. 4. Ecodiagrams of Asarum europacum L. (explanations as in Fig. 2) 

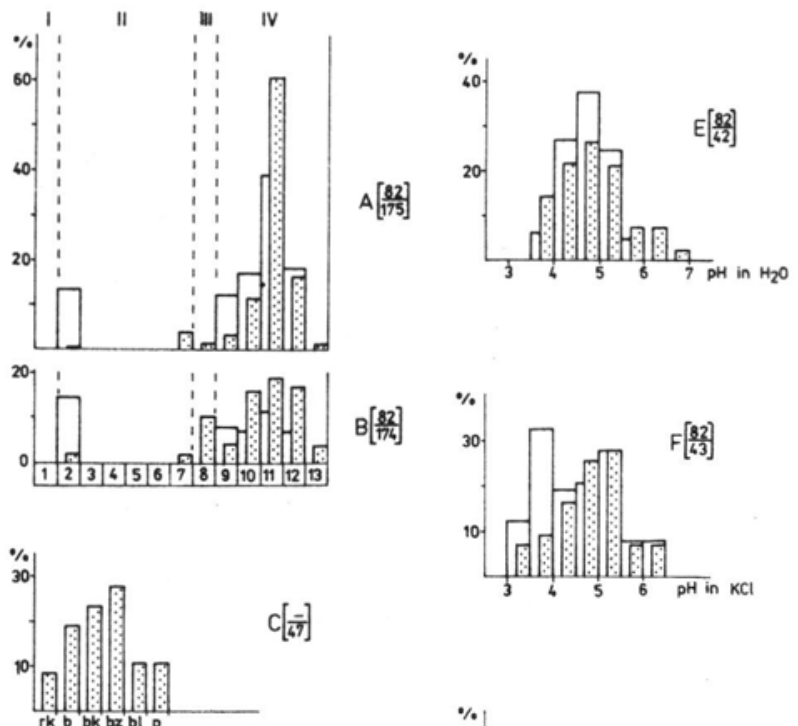

$c[\bar{k}]$

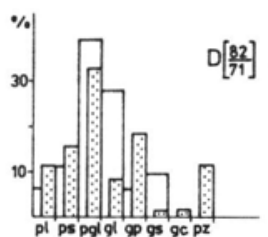

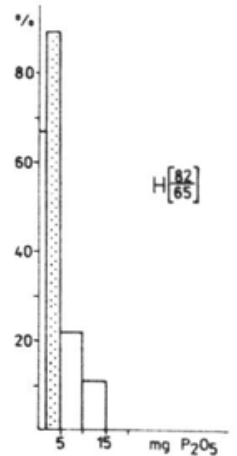
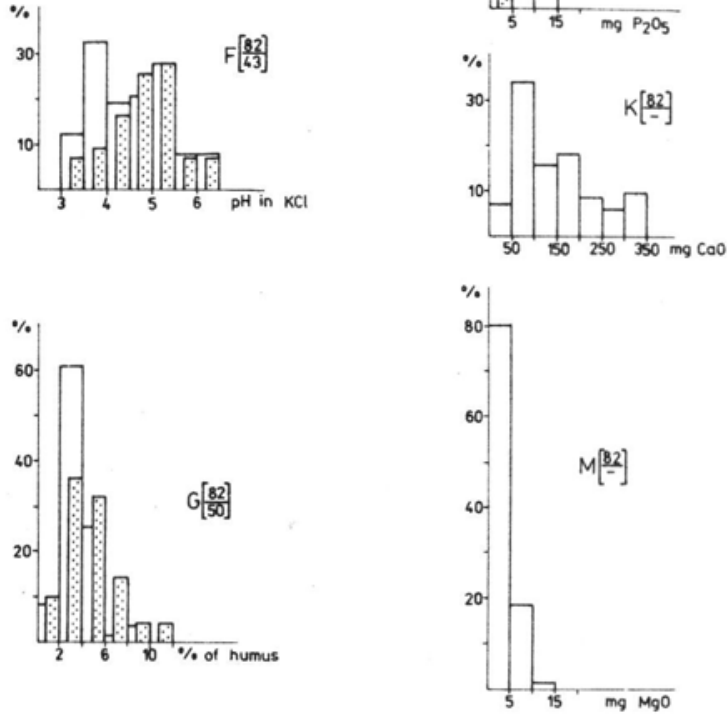

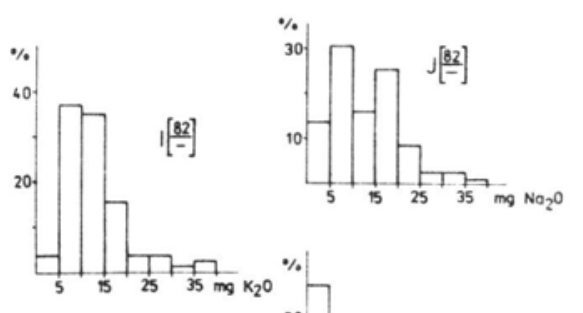

Asperula odorata L.
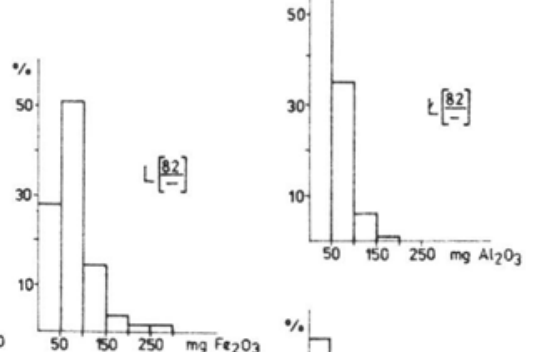

Fig. 5. Ecodiagrams of Asperula odorata L. (explanation as in Fig. 2)

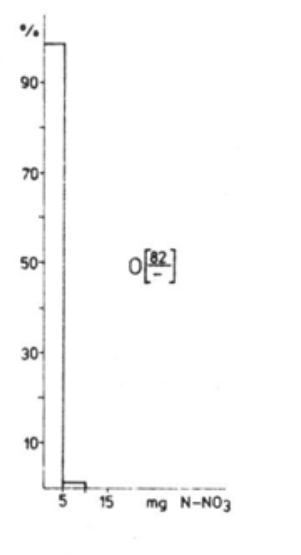



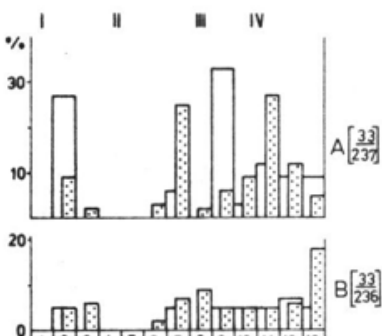

$B\left[\frac{33}{236}\right.$

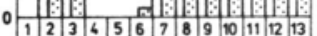
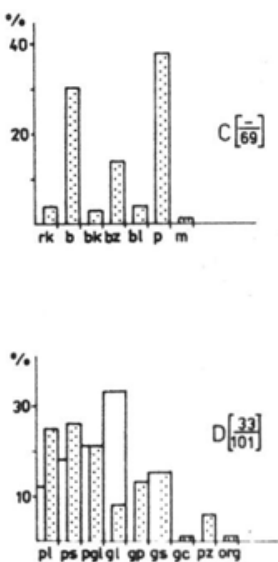
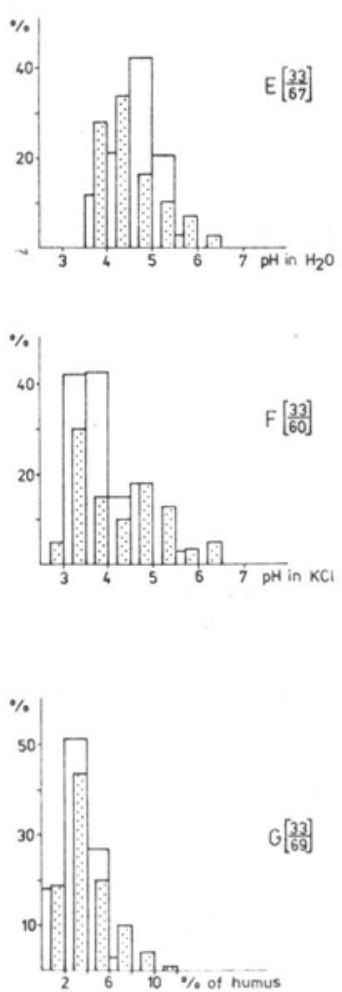

Carex digitata
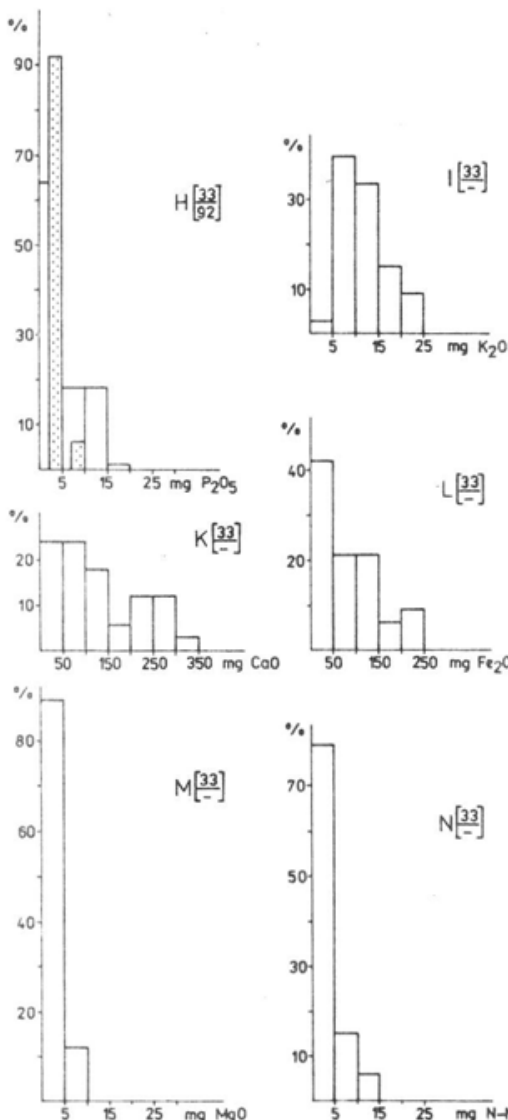

$\%$

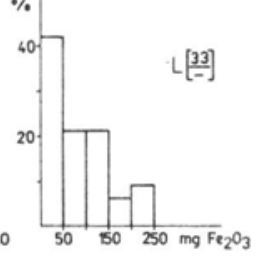

$[33]$
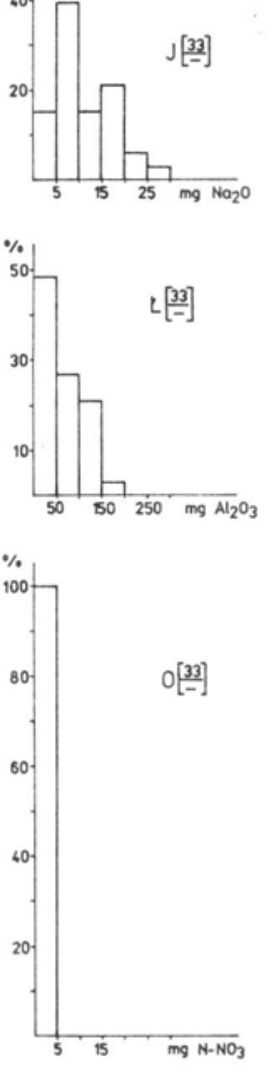

Fig. 6. Ecodiagrams of (arex digitata L. (explanations as in Fig. 2) 


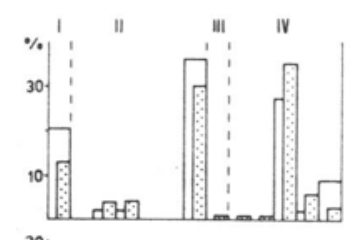

A[约]

20.
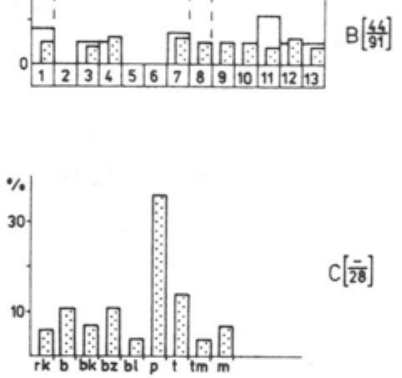

$c[\overline{\overline{20}}]$
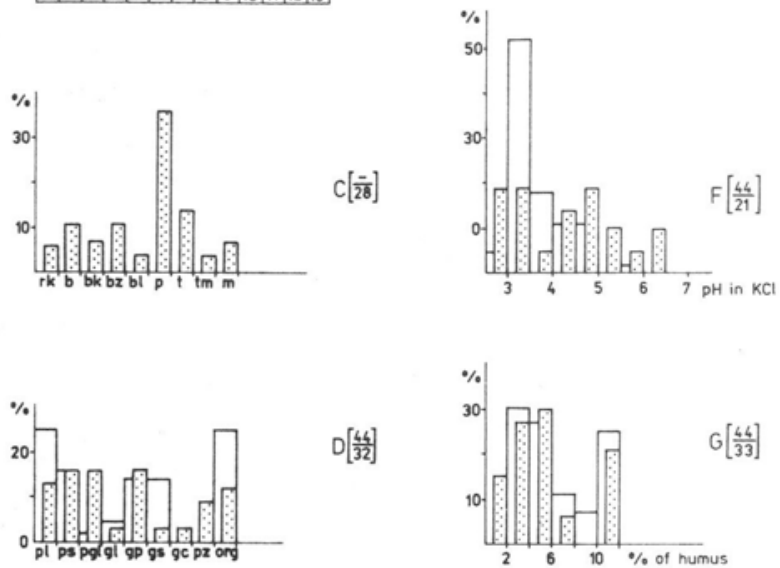

$0\left[\frac{4}{32}\right]$
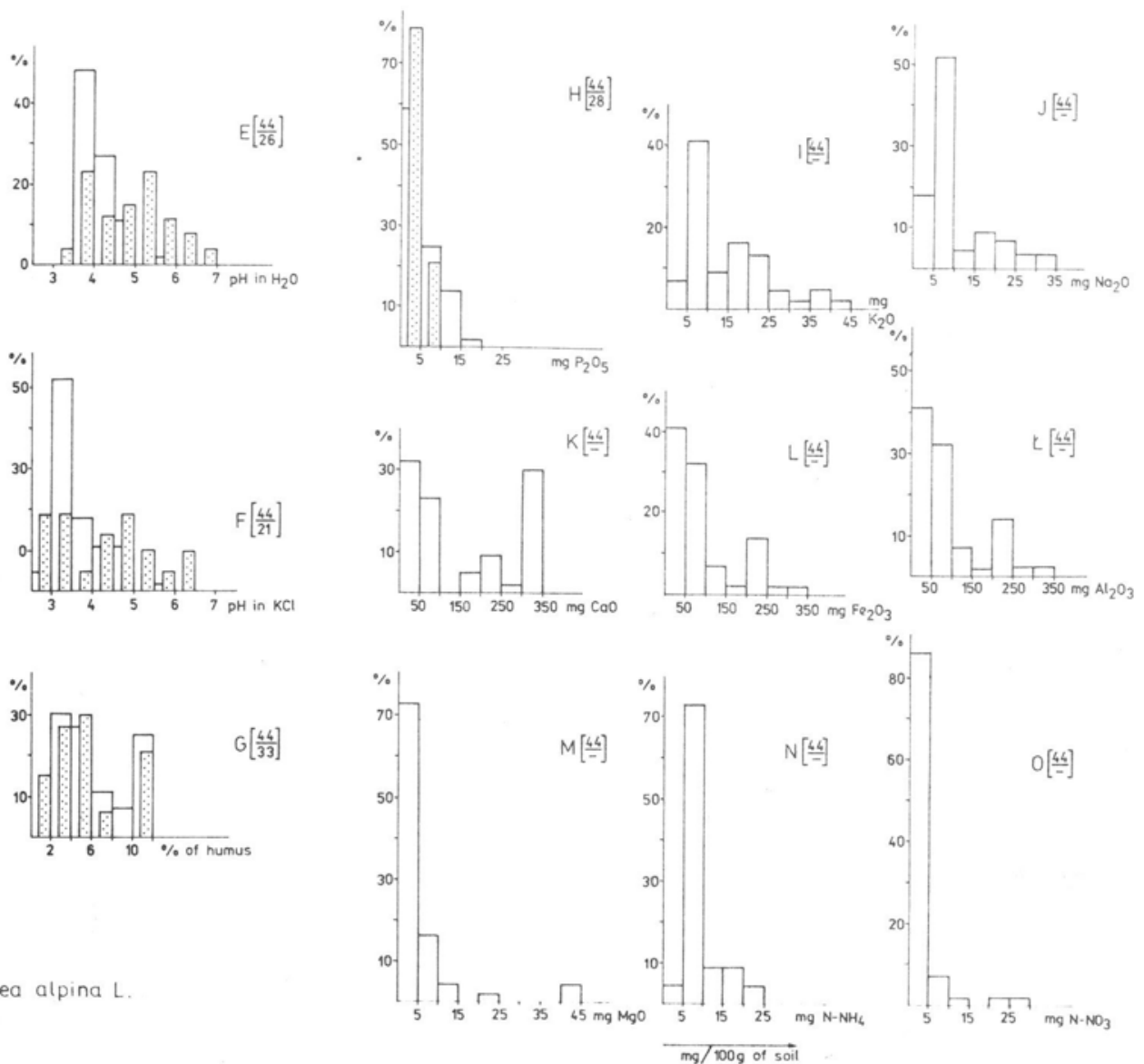

Circaed alpina L.

Fig. 7. Ecodiagrams of Circaea alpina L. (explanations as in Fig. 2) 

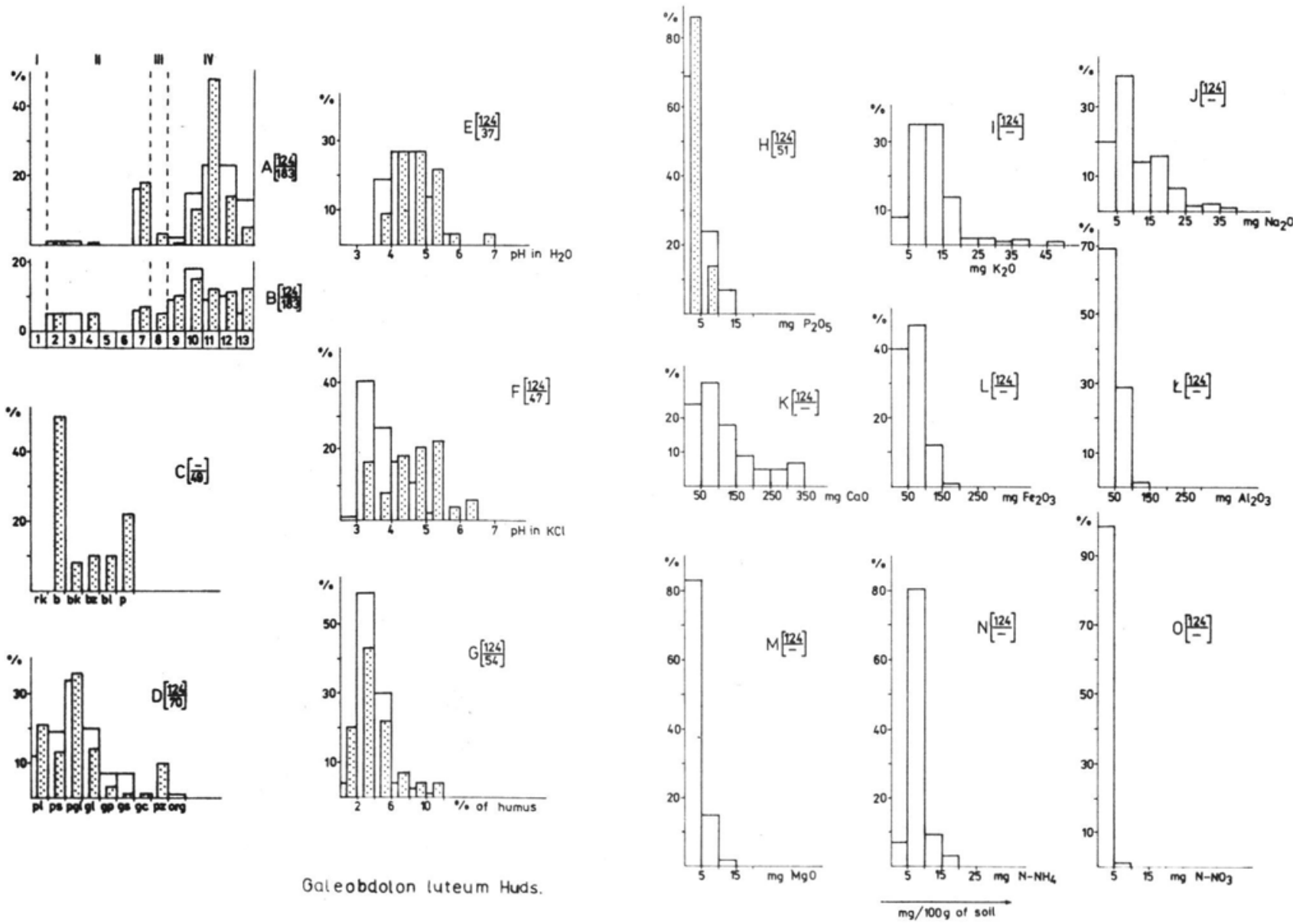

Galeobdolon luteum Huds.

Fig. 8. Ecodiagrams of Galeohdolon luteum Huds. (explanations as in Fig. 2) 

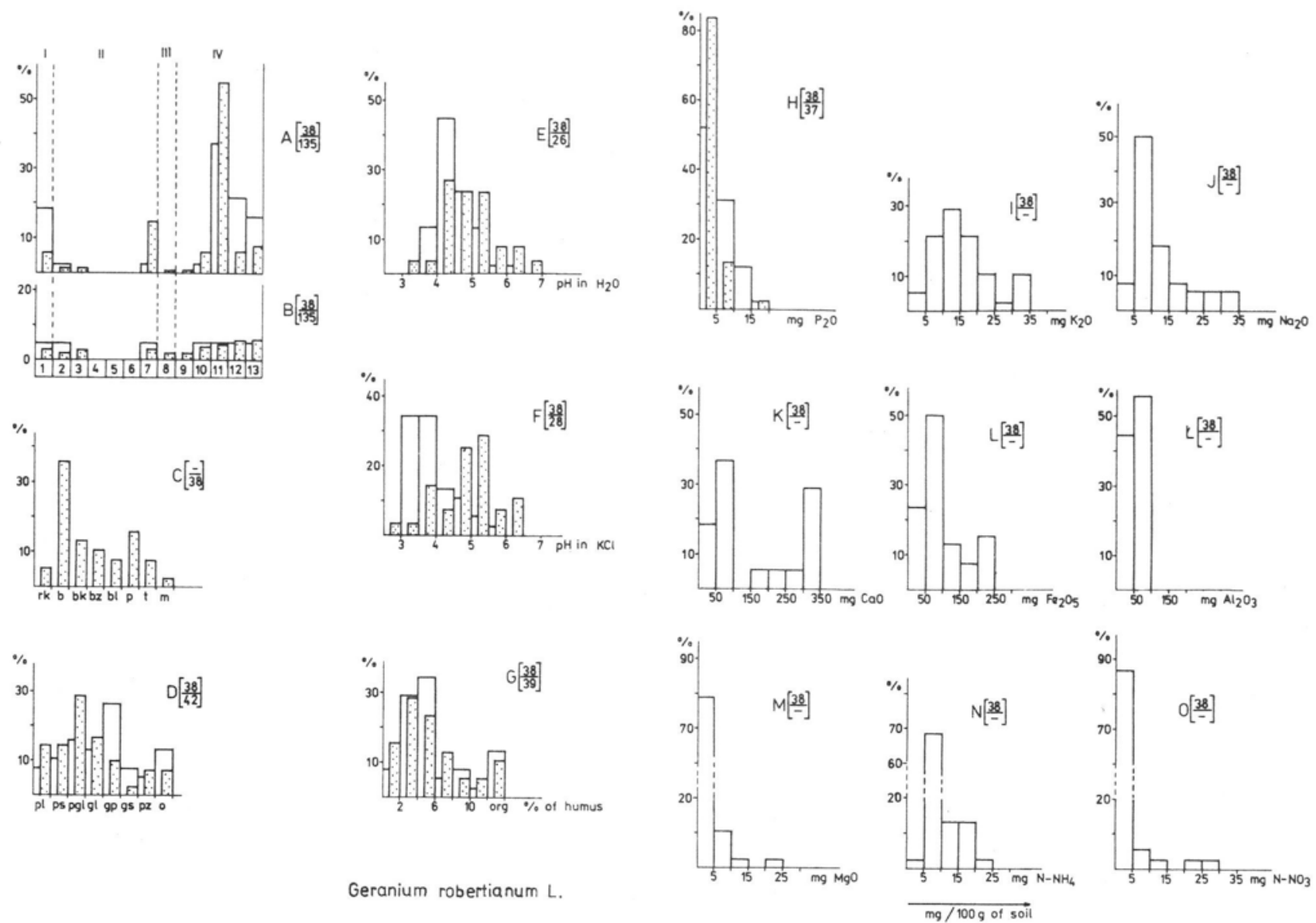

Geranium robertianum L.

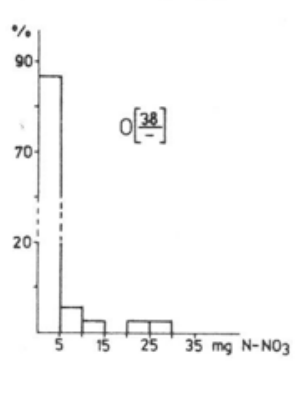

Fig. 9. Ecodiagrams of Geranium robertianum L. (explanations as in Fig. 2) 

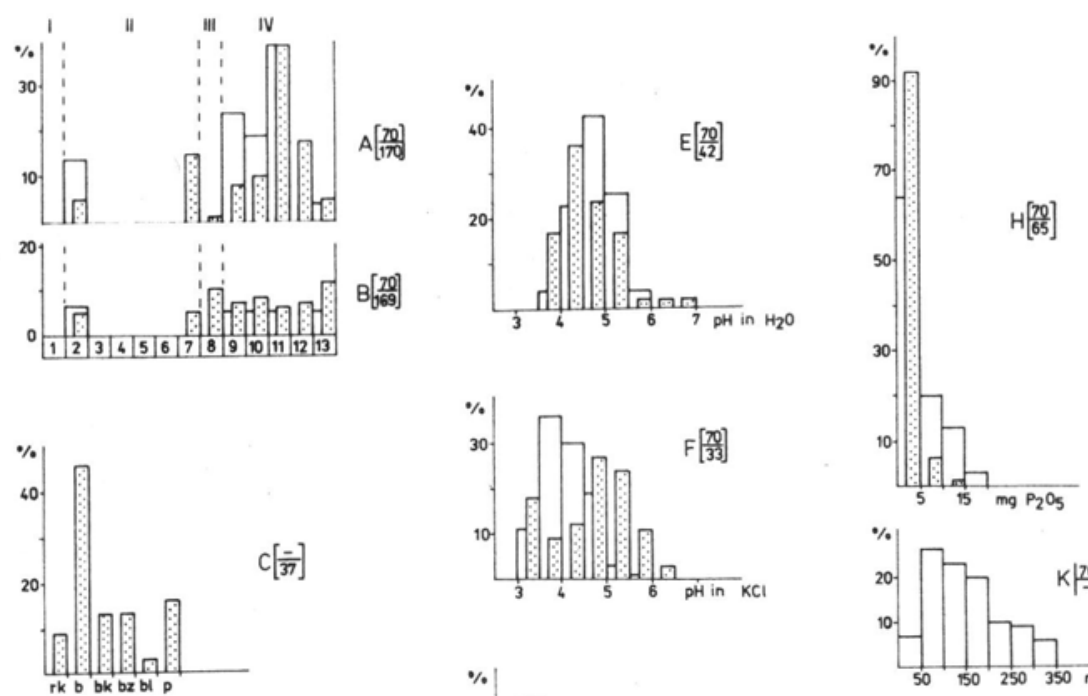

$c[\bar{n}]$
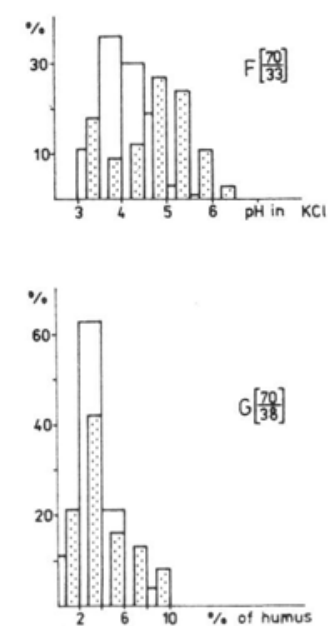

Hepatica nobilis Garsault

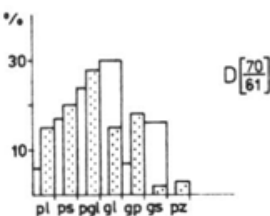

$0\left[\frac{70}{6]}\right]$
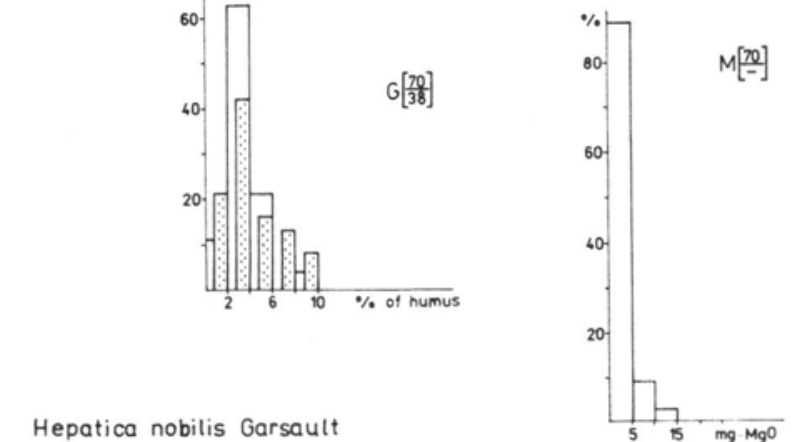
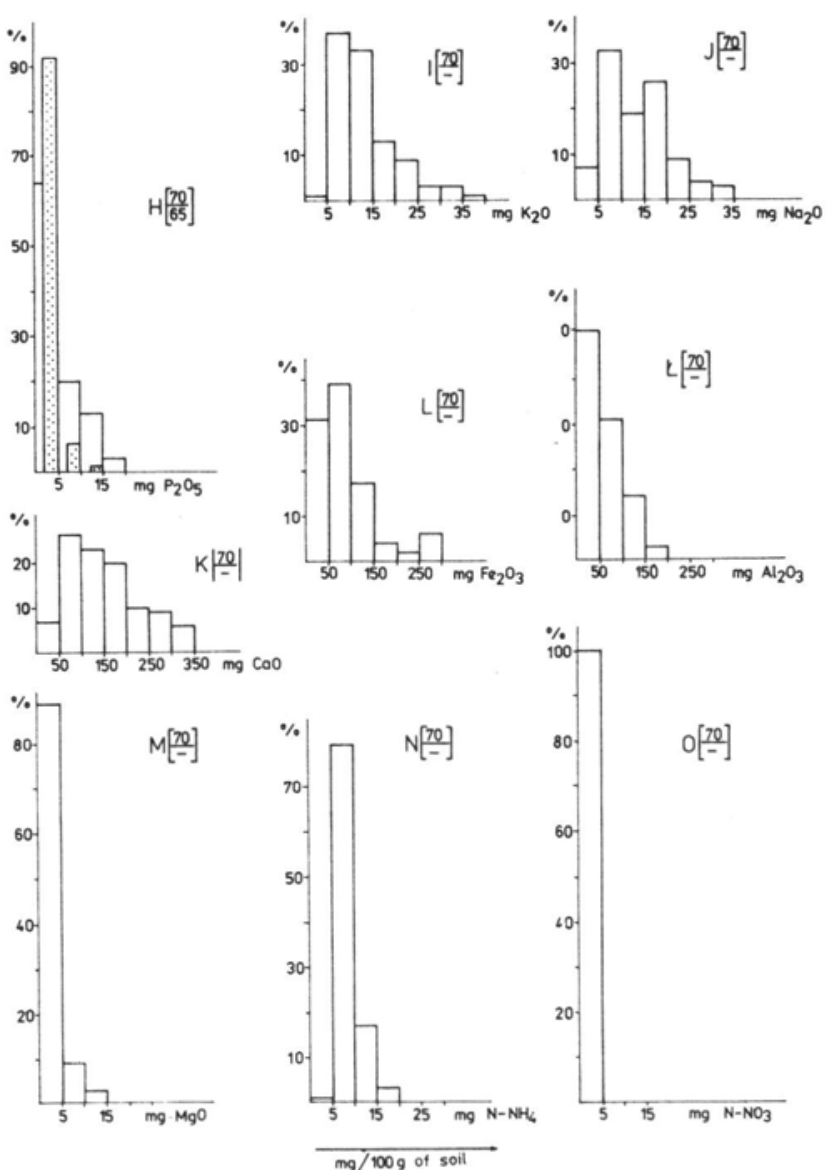

Ryc. 10. Ecodiagrams of Hepatica nobilis Garsault (explanations as in Fig. 2) 


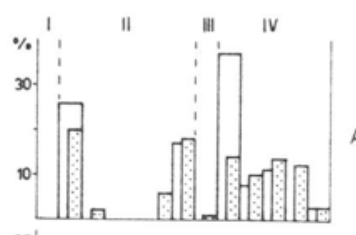

20ㄴ.

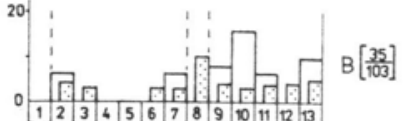

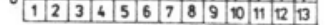

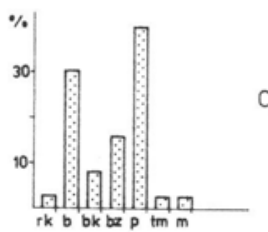

$c[\overline{\bar{x}}]$

$A\left[\frac{35}{102}\right]$
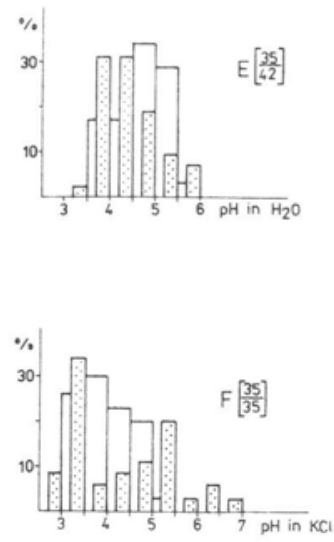

त. If: 179
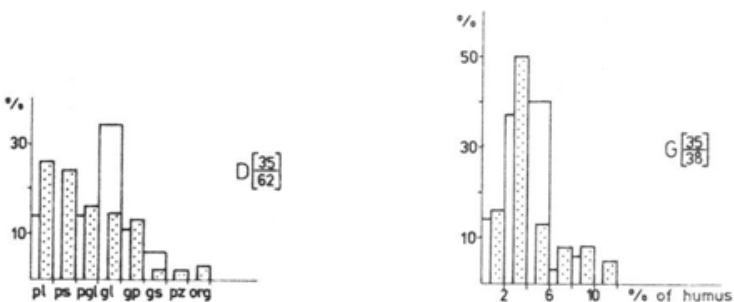
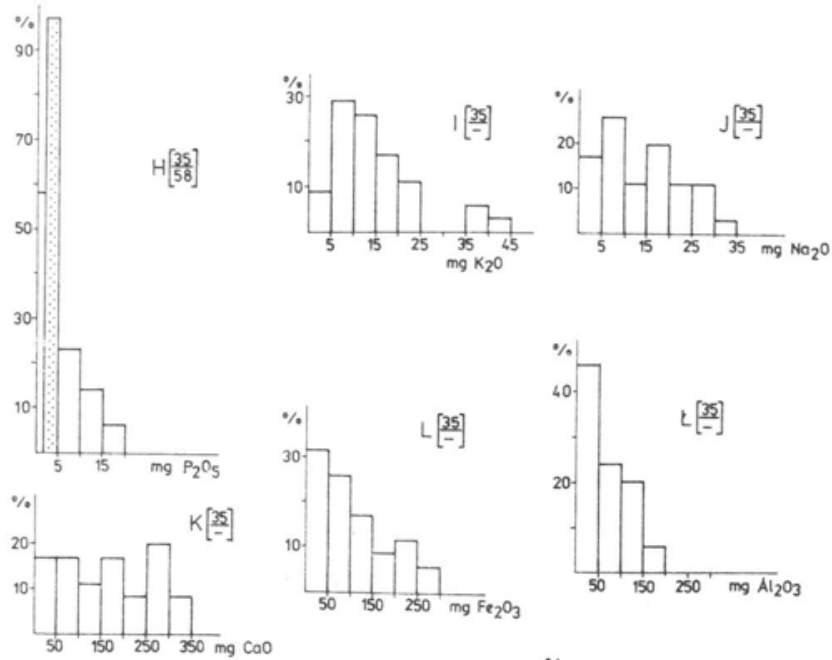

Melica nutans L.
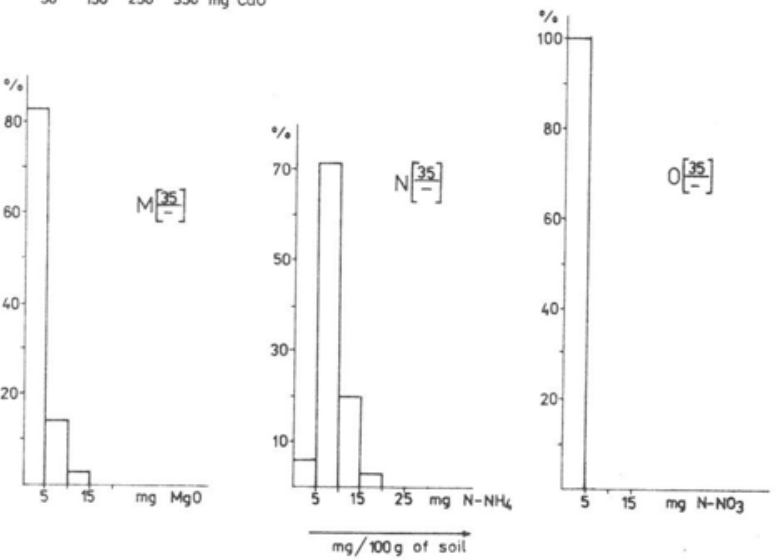

Fig. 11. Ecodiagrams of Melica nutans L. (explanations as in Fig. 2) 


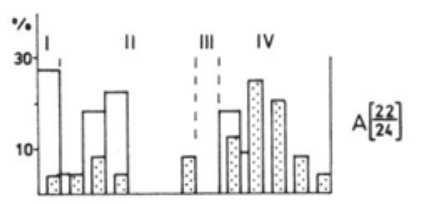

${ }^{20} 1$
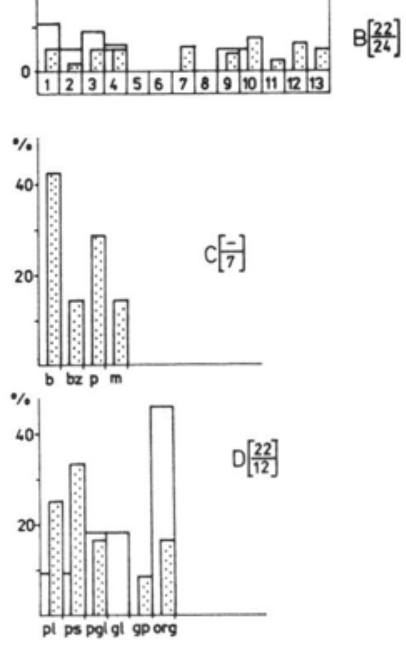
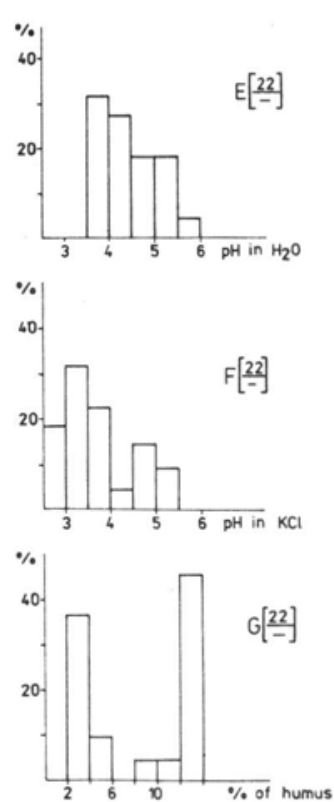
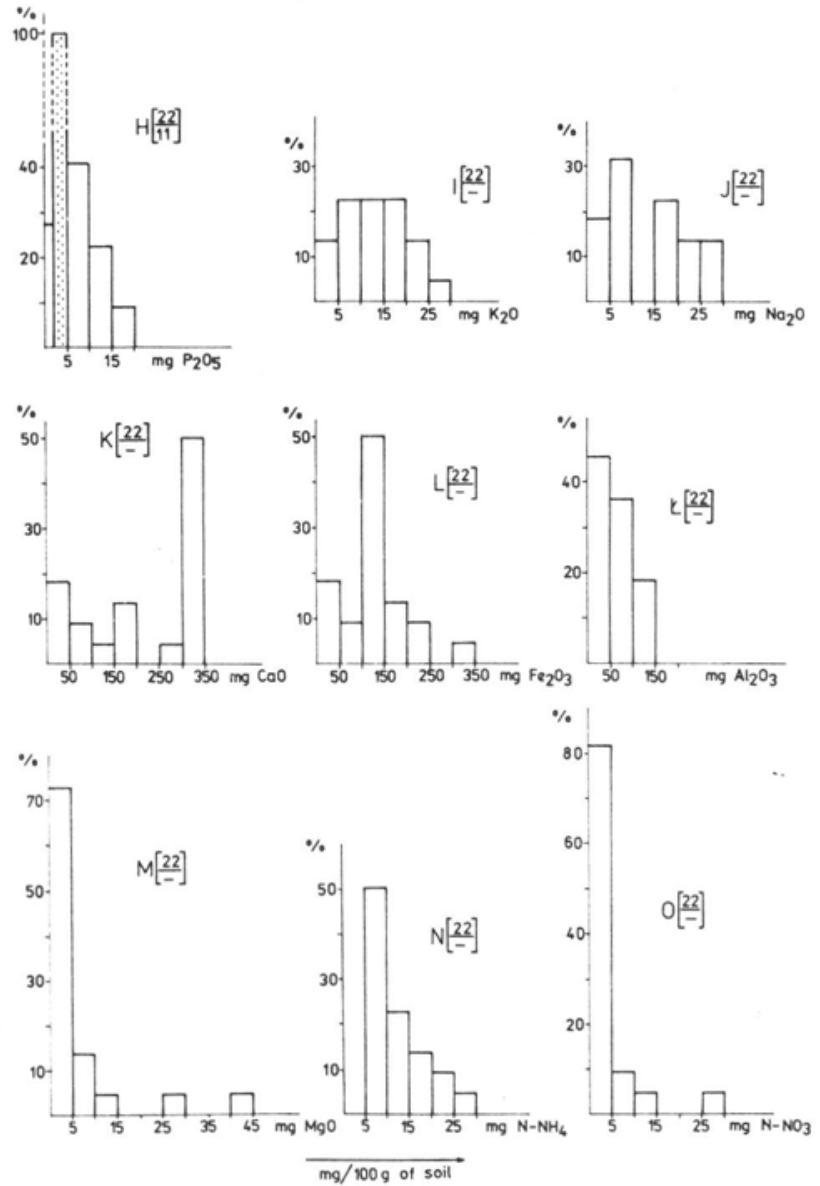

Milium effusum $\mathrm{L}$.

Fig. 12. Ecodiagrams of Milium effusum L. (explanations as in Fig. 2) 

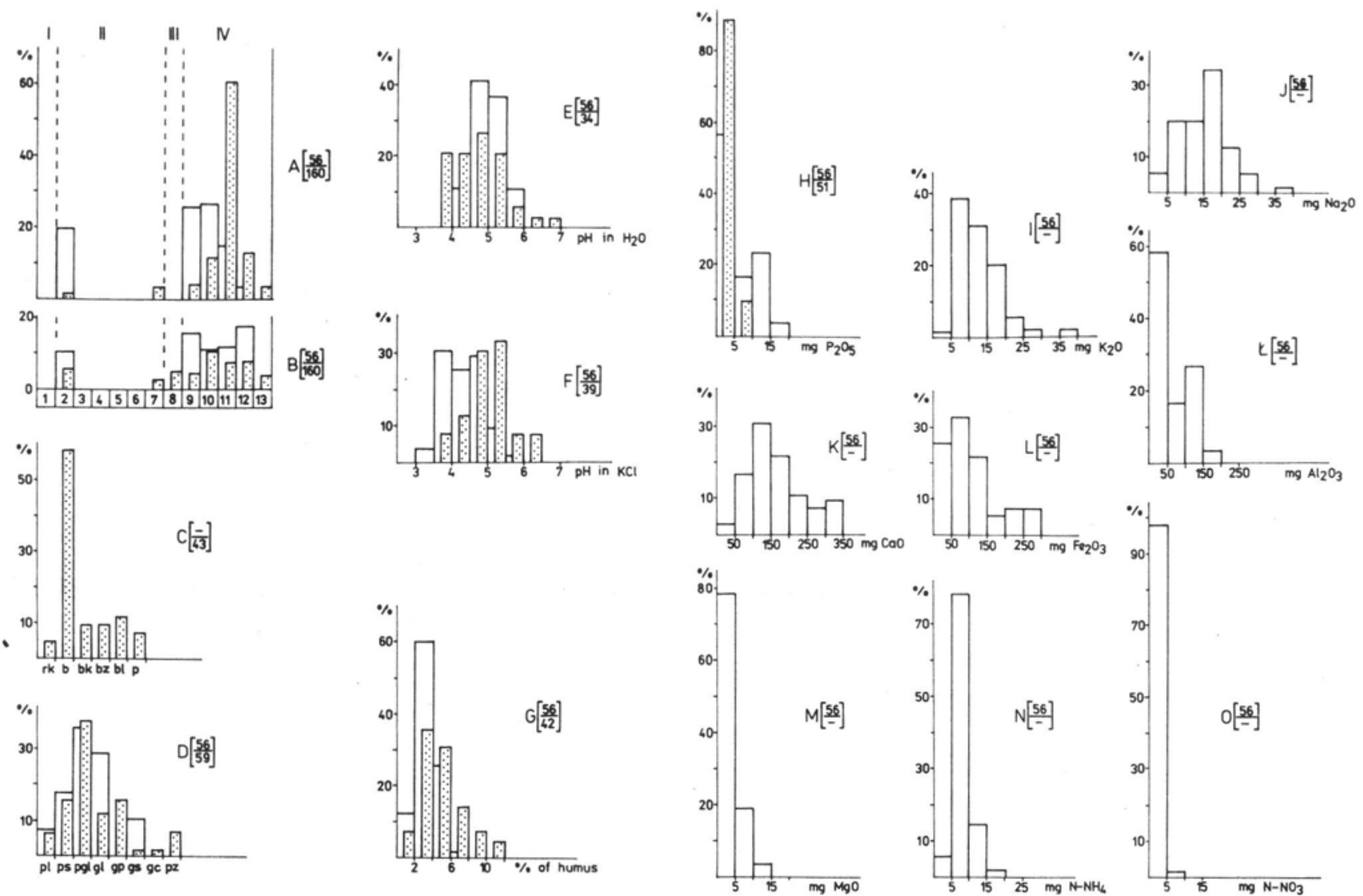

Fig. 13. Ecodiagrams of Pulmonaria obscura Dum. (explanations as in Fig. 2) 

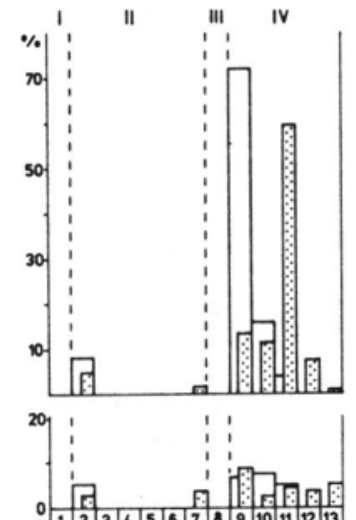

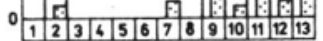

$\%$

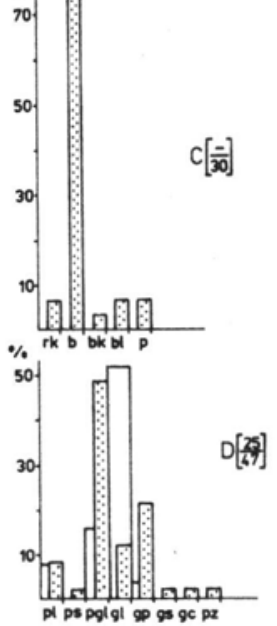

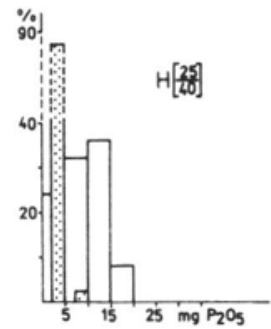

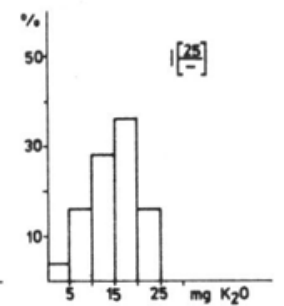

50
50

$\sqrt{[2 x}]$

$\frac{\mathbb{H}}{\infty}$
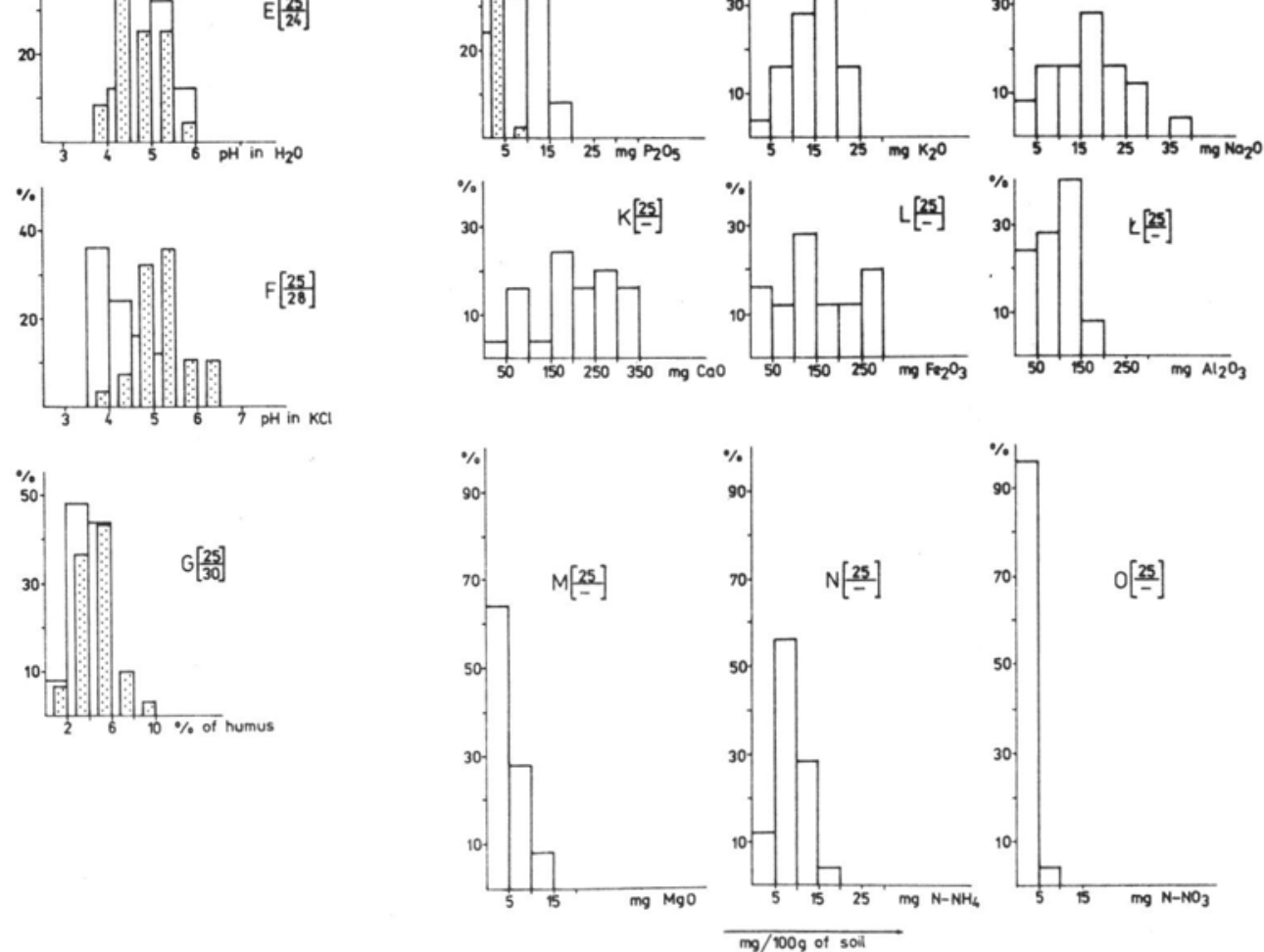

Sanicula europaea L.

Fig. 14. Ecodiagrams of Sanicula curopaea L. (explanations as in Fig. 2) 


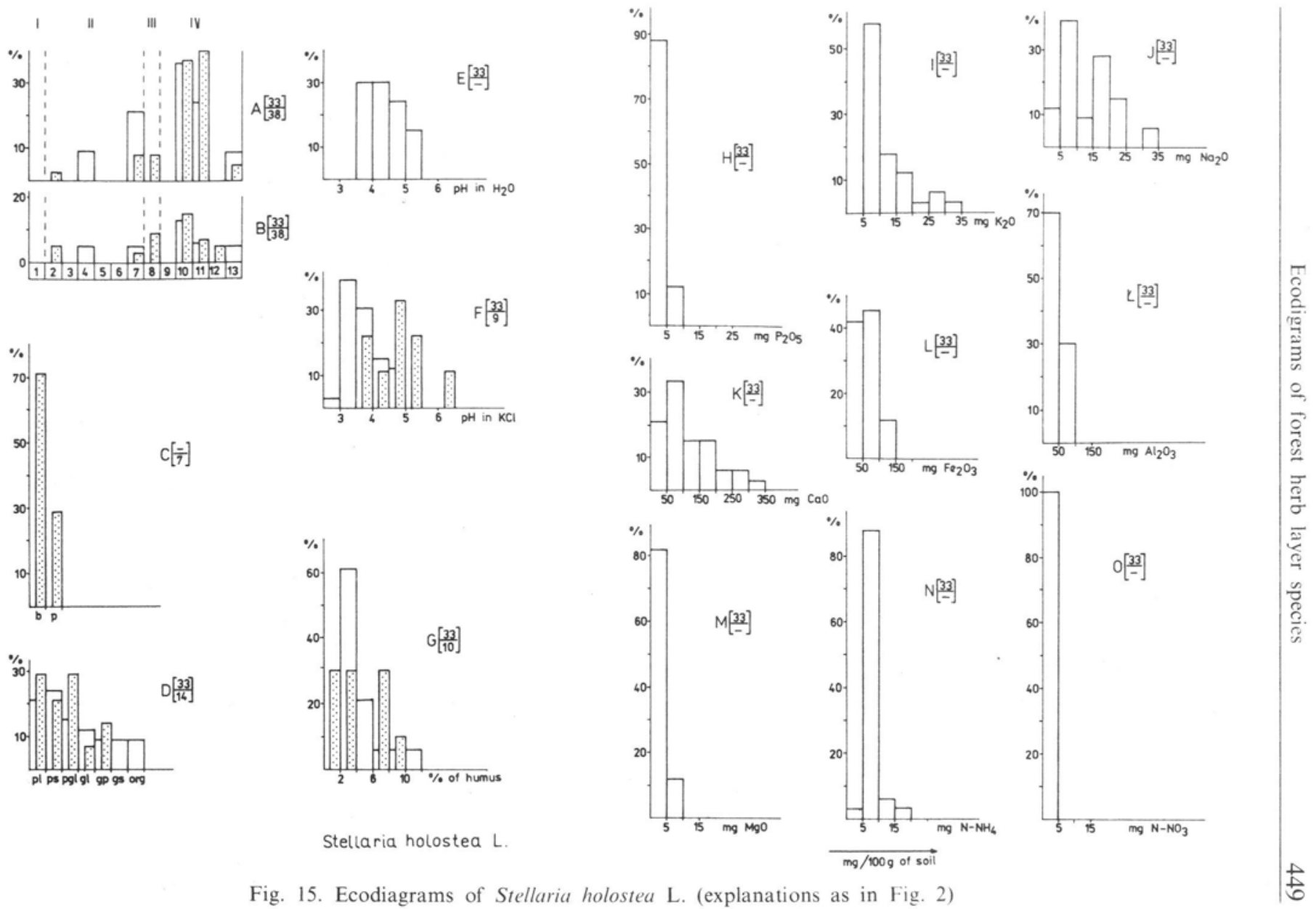




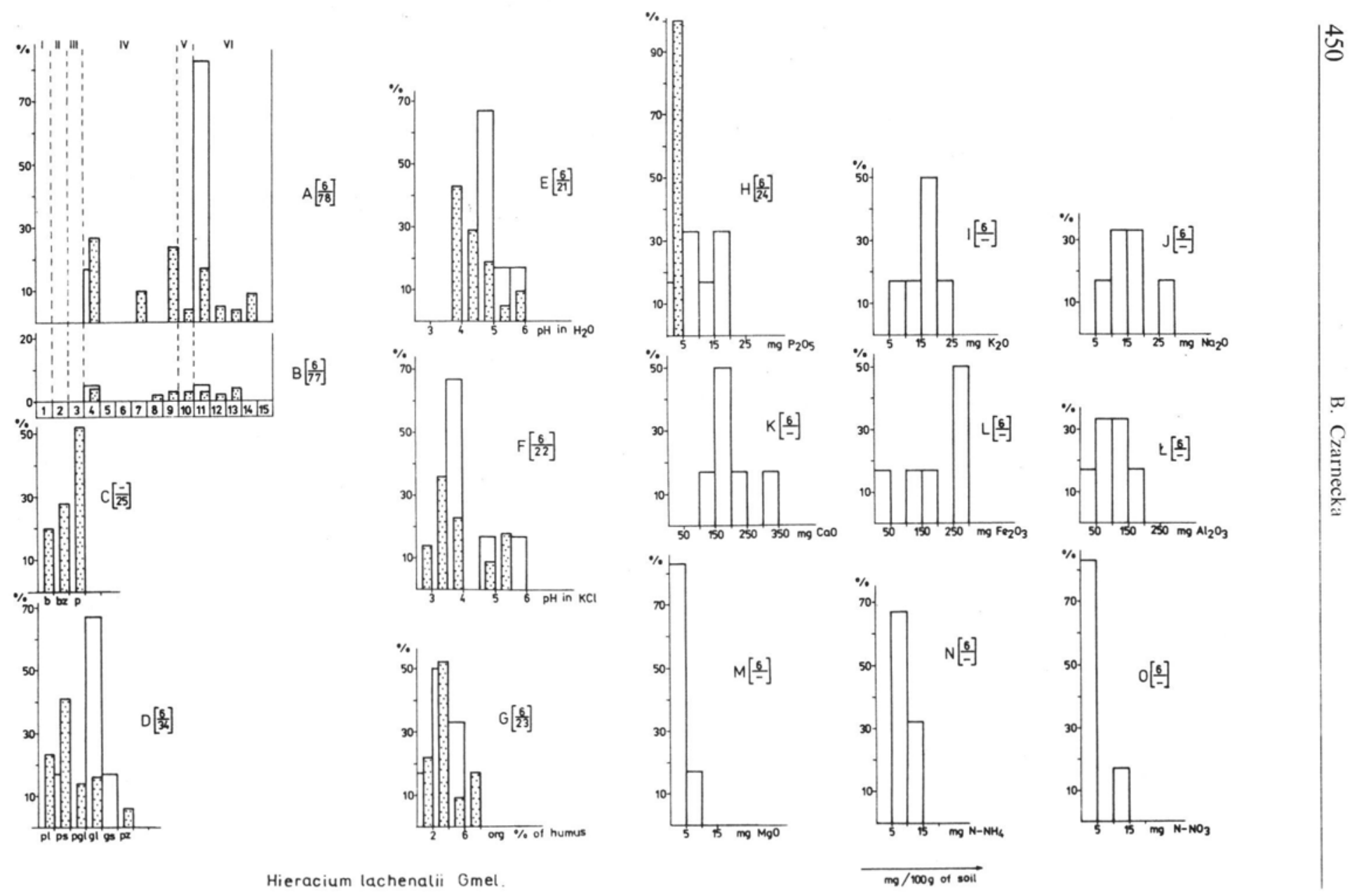


Soils samples collected from the study squares where common species characteristic for forest of the class Querco-Fagetea are present exhibit a very low aluminium content. The class with $\mathrm{Al}_{2} \mathrm{O}_{3}$ content within the limits of $0-50 \mathrm{mg}$ per $100 \mathrm{~g}$ soil comprises from twenty odd to more than 80 per cent of sites of all species (Figs. 2Ł-15Ł). Only Sanicula europaea differs by a 40 per cent participation of sites in the class with $100-150 \mathrm{mg}$ of this component per $100 \mathrm{mg}$ soil (Fig. 14L).

From 60 to 90 per cent of sites with the studied plant species were recorded on soils deprived of or with barely trace amounts of magnesium, not exceeding $5 \mathrm{mg} \mathrm{MgO}$ per $100 \mathrm{mg}$ soil (Figs. 2M-15M).

Analysis of soil samples indicates a substrate rather poor in nitrogen compounds, e $\mathrm{e}^{\mathrm{r}}$ ecially in nitrate form (Figs. $\left.2 \mathrm{~N}, \mathrm{O}-15 \mathrm{~N}, \mathrm{O}\right)$. Most numerous sites of the species are found on soils with a $5-10 \mathrm{mg}$ per $100 \mathrm{~g}$ soil ammonium nitrogen content, and $80-100$ per cent on soils deprived on nitrate nitrogen or containing hardly detectable $\mathrm{N}-\mathrm{NO}_{3}$ amounts. A somewhat different distribution of sites is noted for three plant species in dependence on the amount of nitrogen compounds: Circaea alpina (Fig. 7N, O), Geranium robertianum (Fig. 9N, O) and Milium effusum (Fig. 12N, O). Analysis of the ecodiagrams indicates that a certain per cent of sites with these species on soils with a higher nitrogen, especially nitrate, content is connected with the high humus content (in the case of $C$. alpina) or of organic matter ( $G$. robertianum and $M$. effusum) in the soils on which these species appear more frequently than other species of this ecological group.

Soils on which the discussed deciduous forest species are found are usually fresh, less frequently they show a higher moisture (peat, muck-mineral and peaty-mineral soils). These sites, as regards trophism manifested in richness in humus or organic matter and a content of nutrient components

Fig. 16. I codiagrams of Hieracium lachenalii Gmel.; I - communitie of the class Scheuchzerio-Caricetea fuscae. II - communities of the class Oxycocco-Sphagnetea. III-communities of the class Alnetea glutinosae IV - communities of the class Vaccinio-Piceetea. V - communities of the class Ouercetea roboris-petraeae. VI-communities of the class Querco-Fagetea; 1 -Caricetum lasiocarpae 2-Ledo-Sphagnetum 3-Carici elongatae-Alnetum 4 -Querco roboris-Pinetum. 5 - Querco-Piceetum 6 - forest community with Carex bryzoides 7 -Vaccinio uliginosi-Pinetum. 8 - Leucobryo-Pinetum. 9-Abietetum polonicum. 10-Fago-Quercetum petraeae. 11 -Potentillo albae-Quercetum, 12 - Tilio-Carpiletum and communities of the order Fagctalia with a predominance of Carpinus betulus 1? - Dentario glandulosae-Fagetum 14 -. impoverished form of Carpathian beechwood and communities of the order Fagelalia with pine 15-fir communities of the class Querco-Fagetea. Remaining explanations 

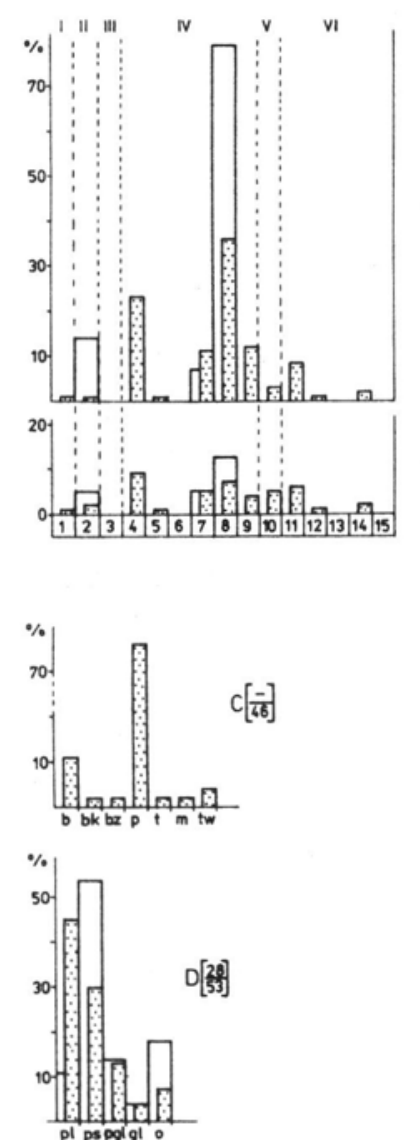
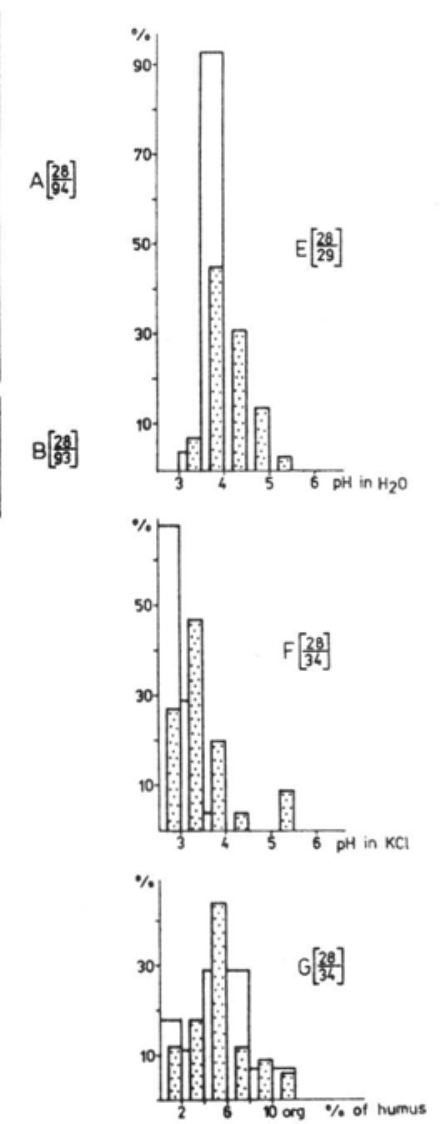
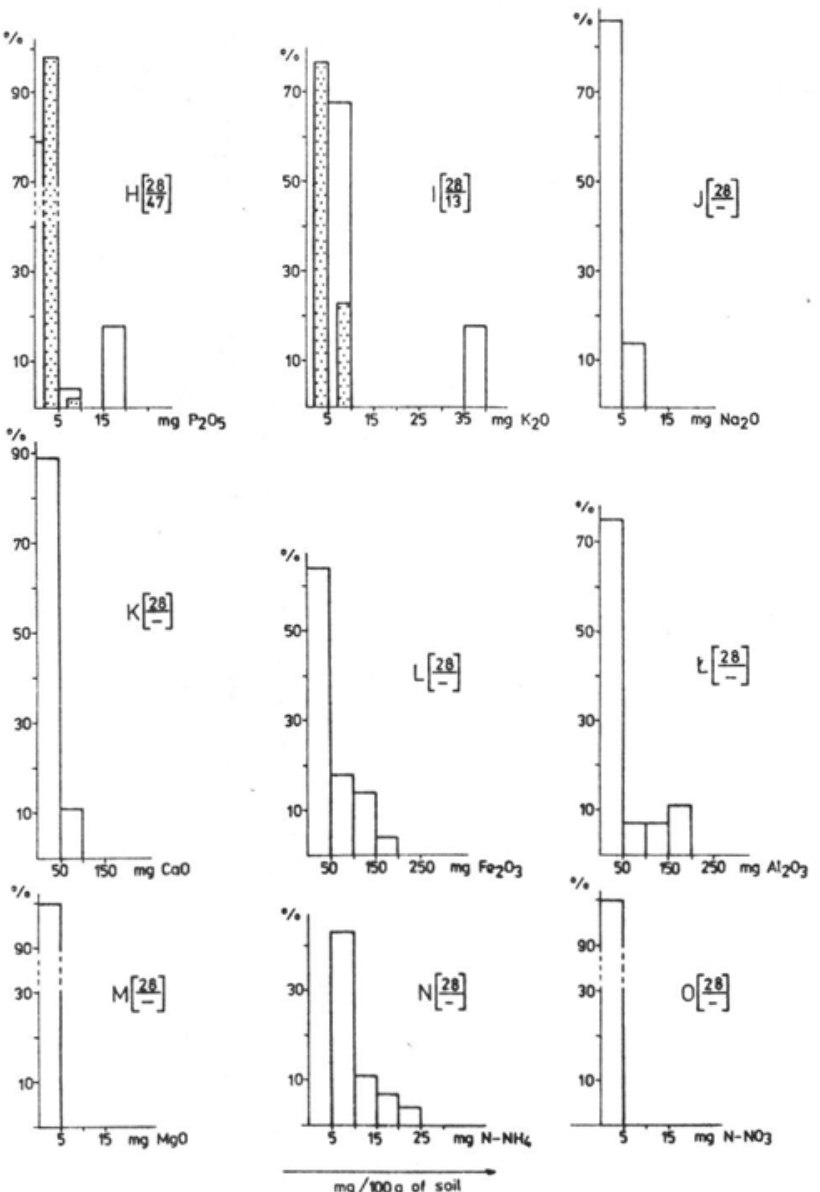

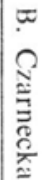

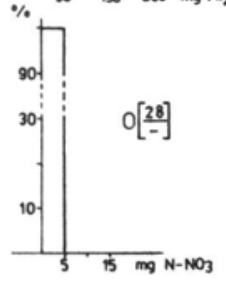

Melampyrum pratense L

Fig. 17. Ecodiagrams of Melampyrum pratense L. (explanations as in Fig. 16) 

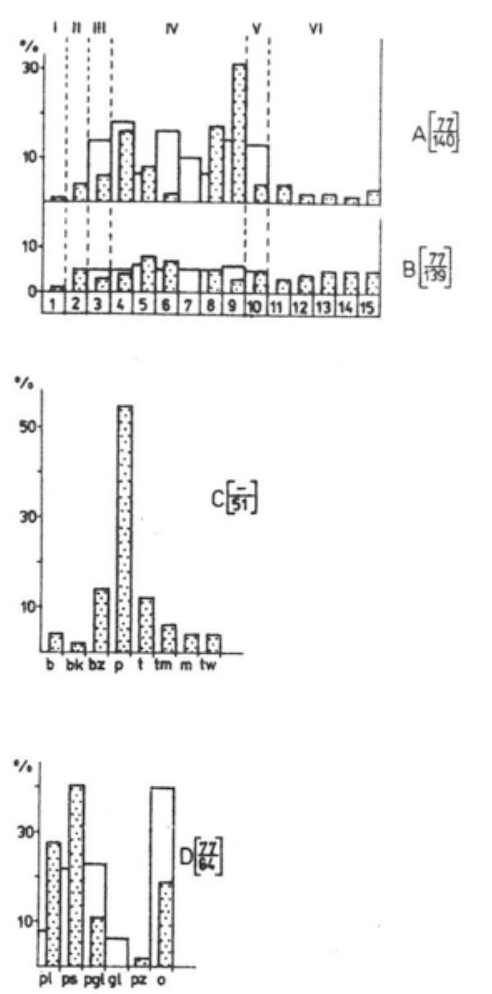
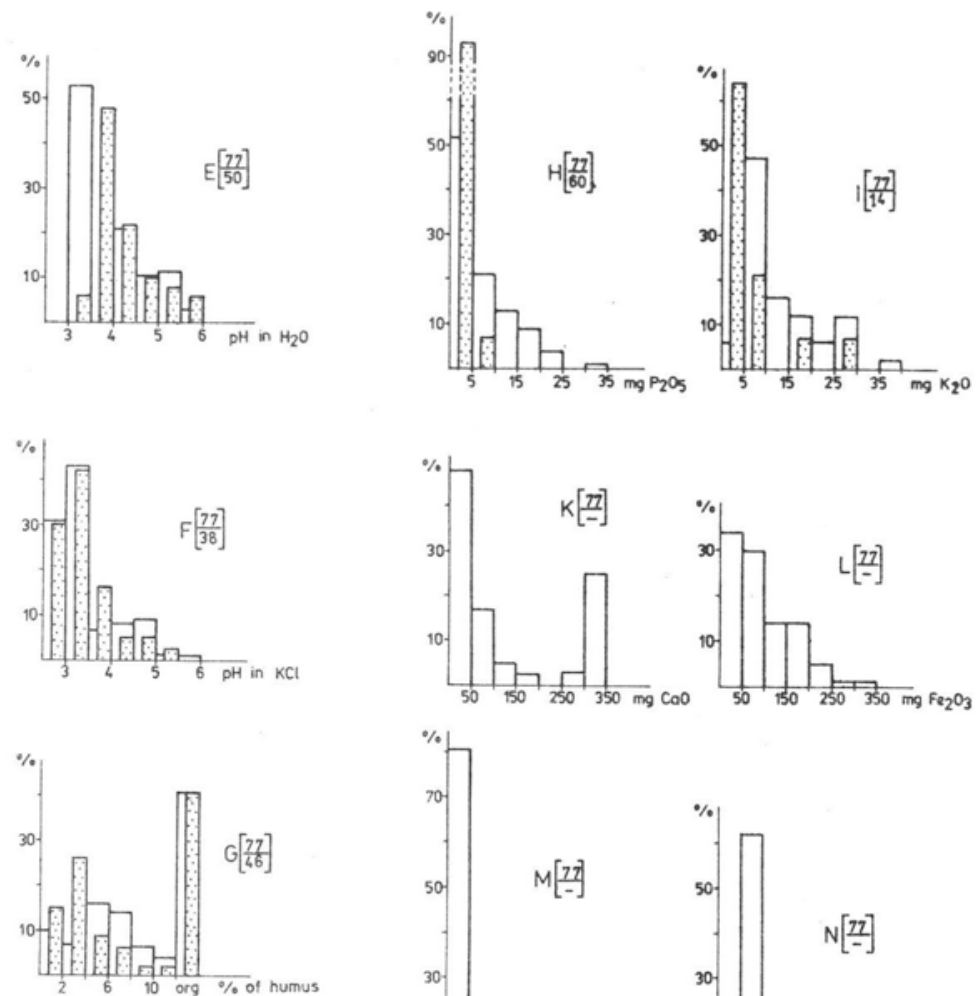

Trientalis europaea $L$.
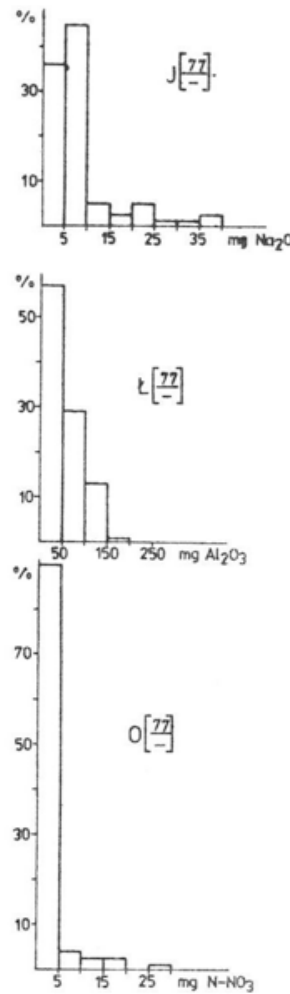

Fig. 18. Ecodiagrams of Trientalis europaea L. (explanations as in Fig. 16) 

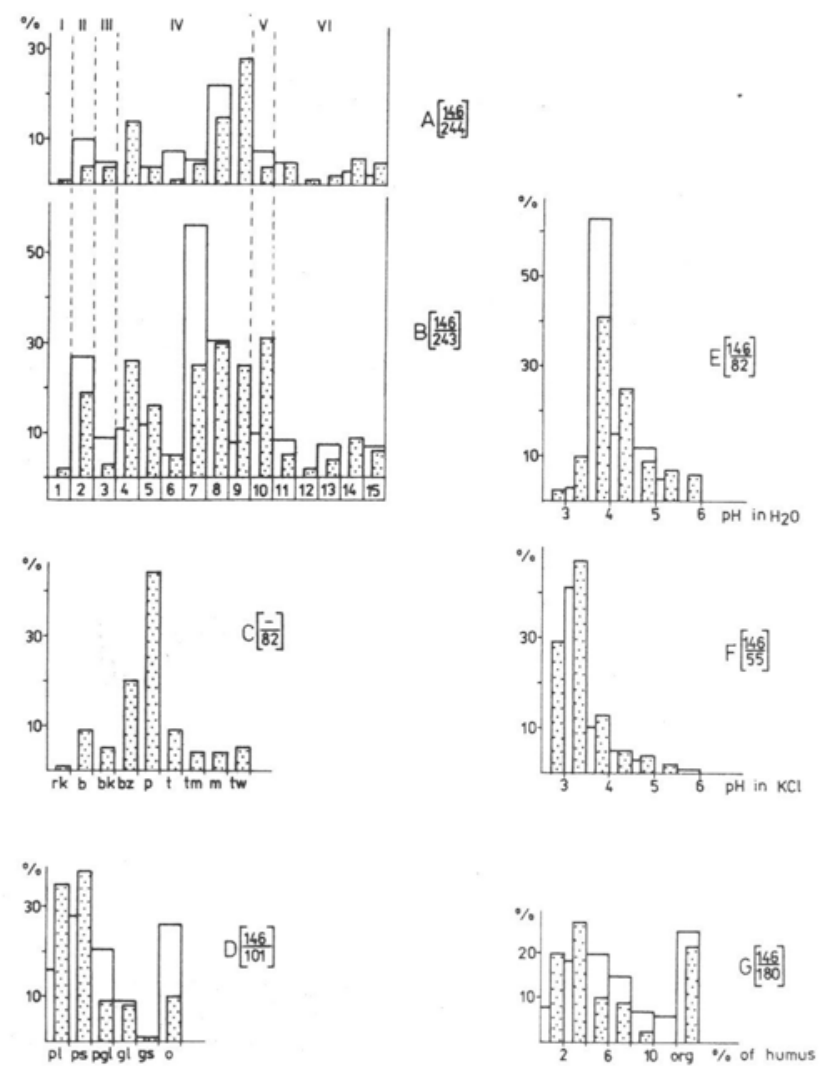

$A\left[\frac{156}{244}\right]$
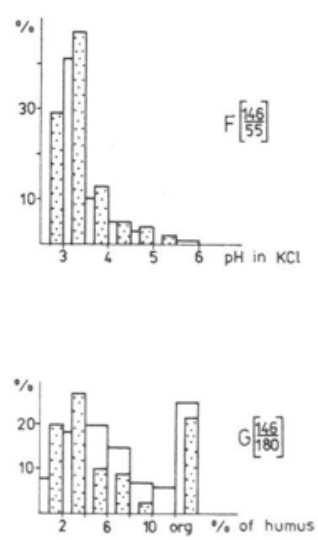
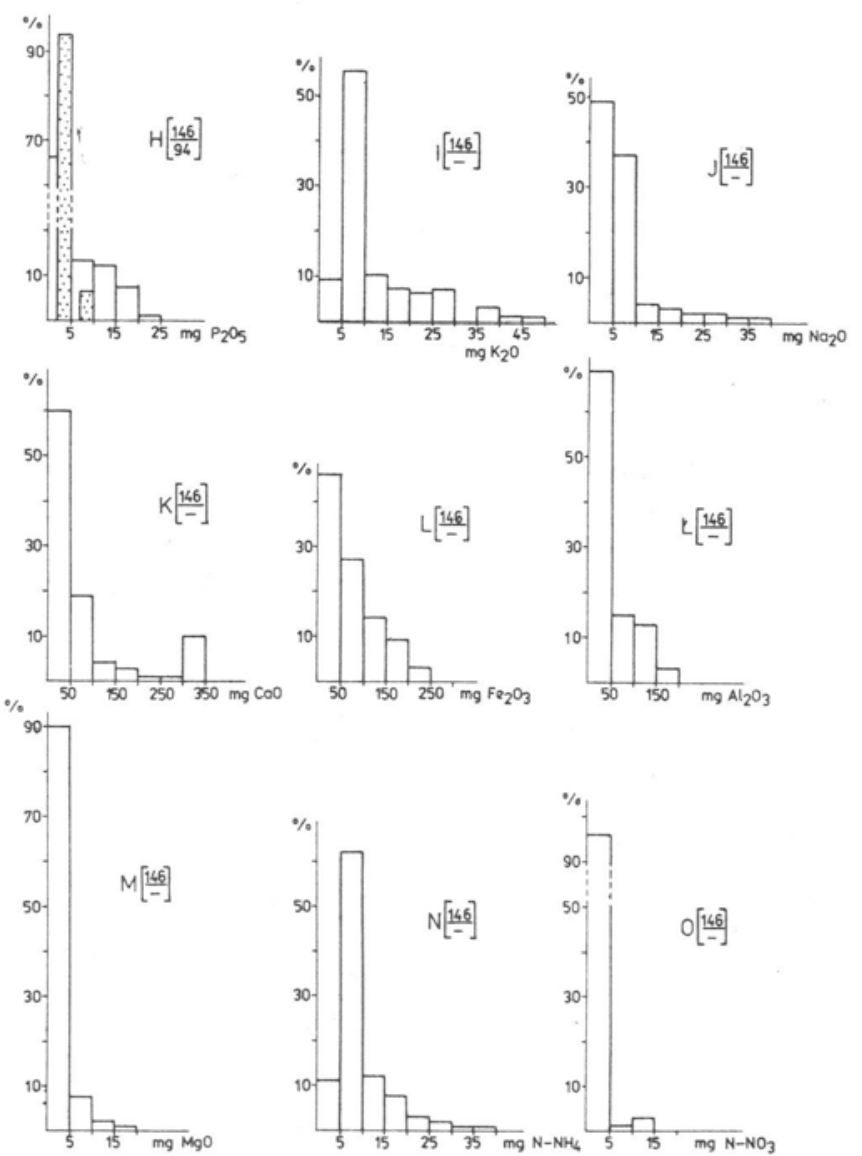

悹

مَ

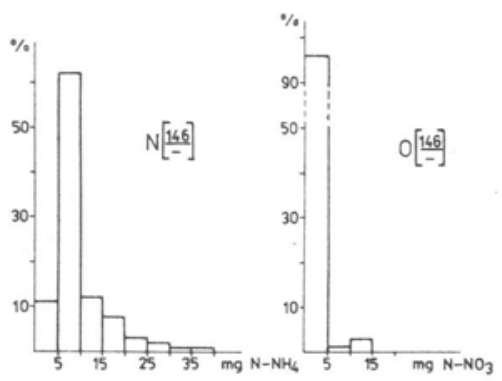

Vaccinium myrtillus L.

$\mathrm{mg} / 100 \mathrm{~g}$ of soil

Fig. 19. Ecodiagrams of Vaccinium myrtillus L. (explanations as in Fig. 16) 

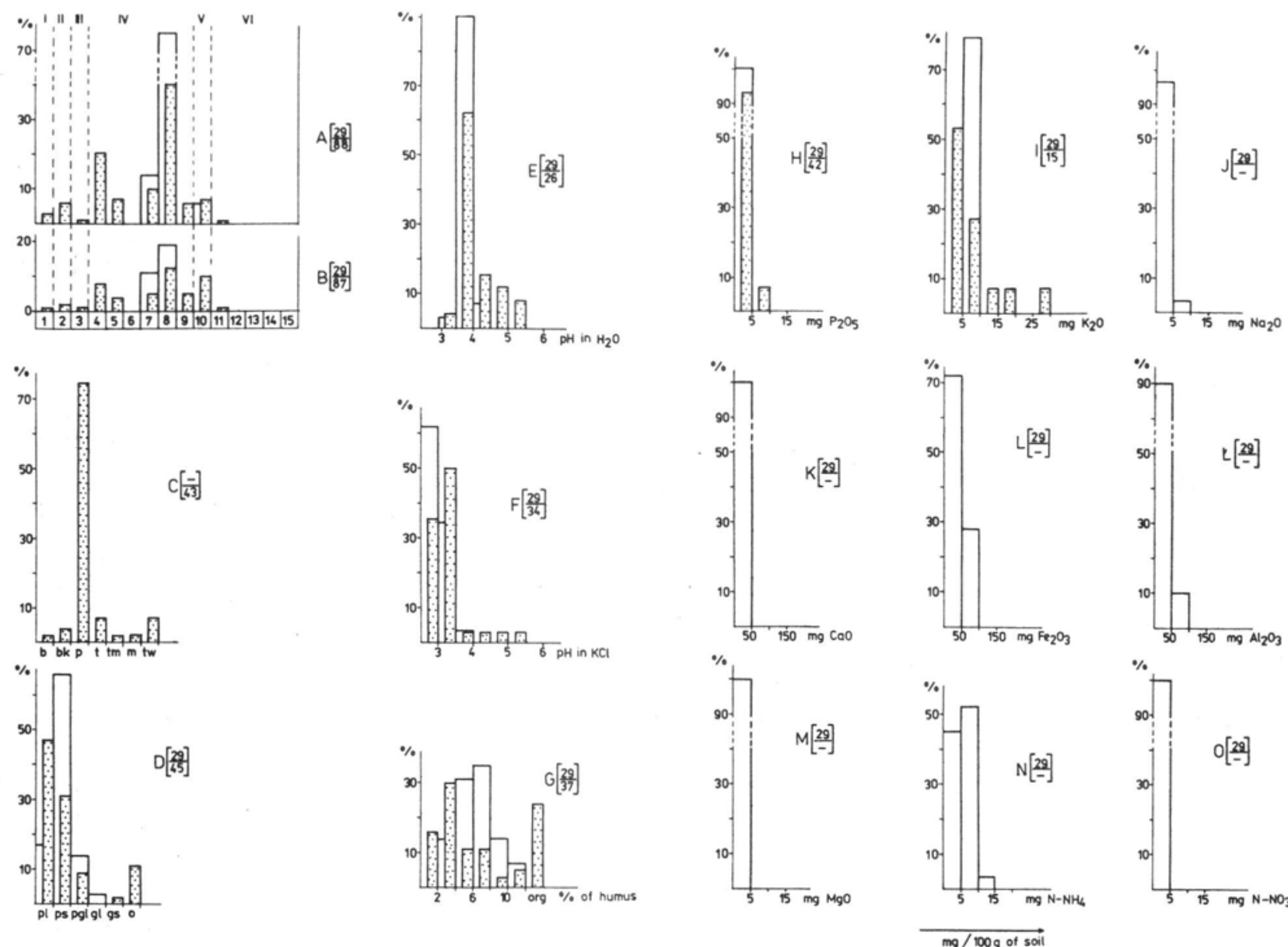

Vaccinium vitis-idaea L.

Fig. 20. Ecodiagrams of Vaccinium vitis-idaea L. (explanations as in Fig. 16) 


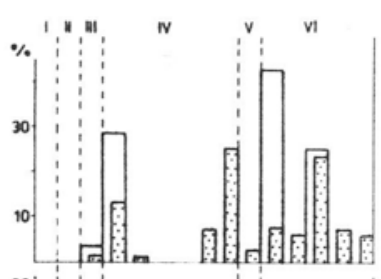
2어 :<smiles>c1ccc2ccccc2c1</smiles>

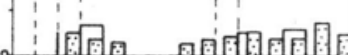

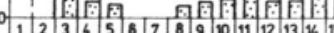
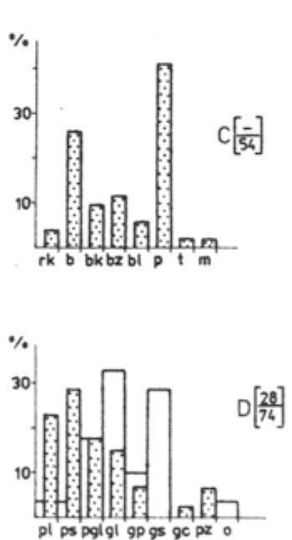
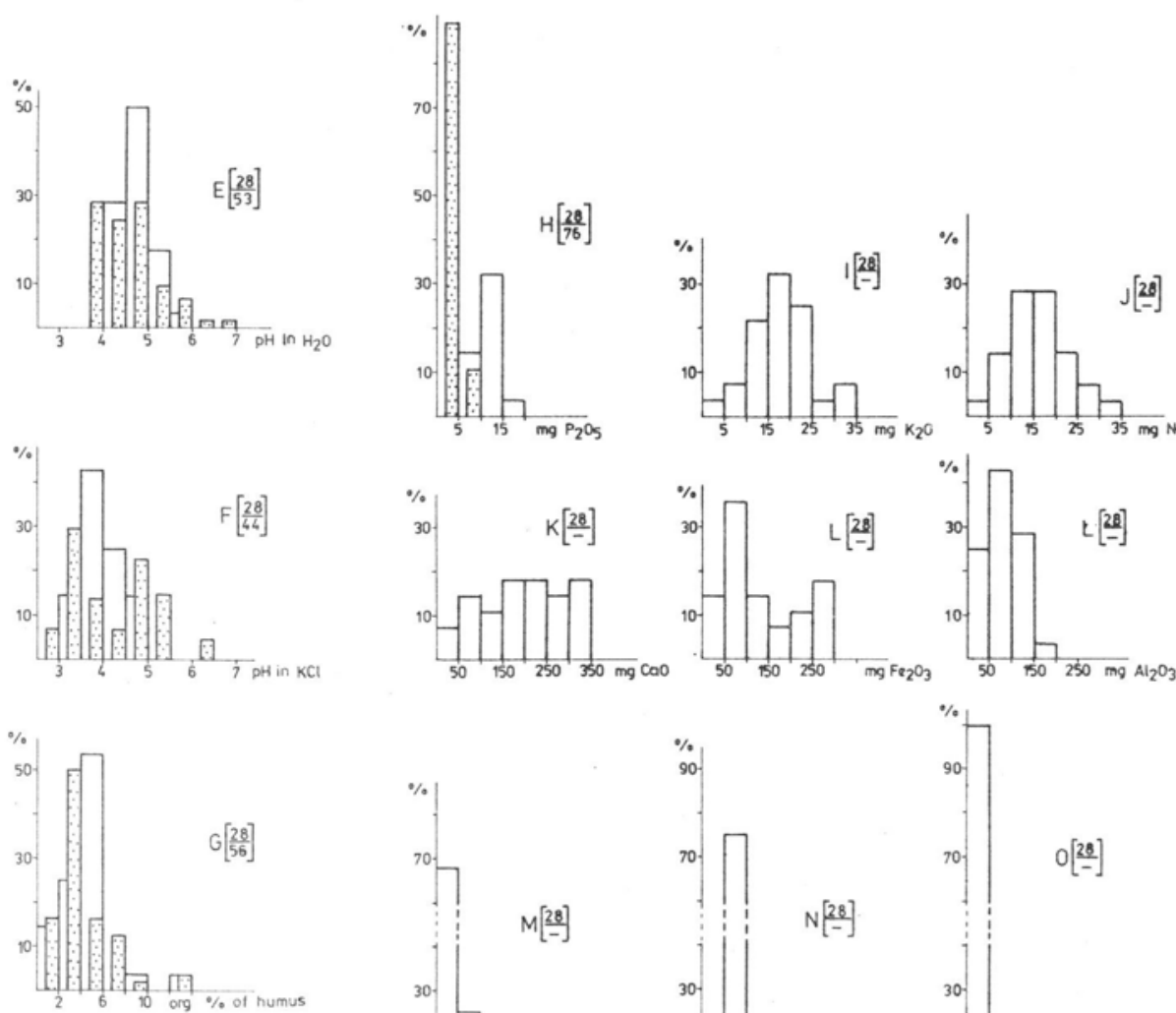

Fragaria vesca
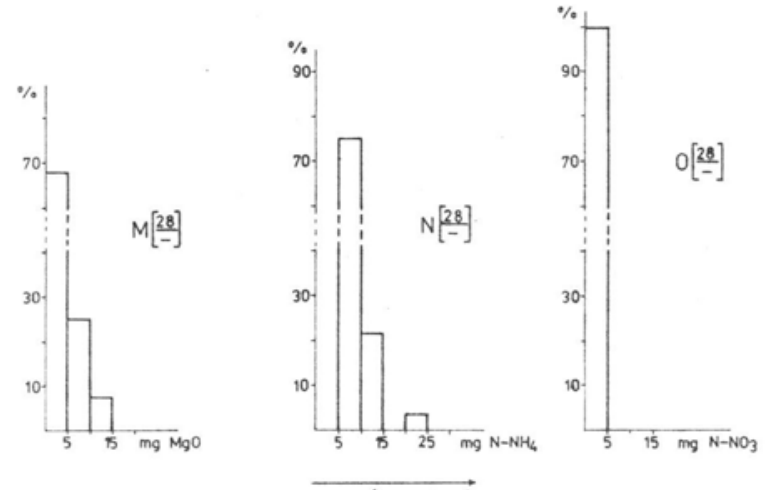

Fiv. 21 Ecodiagrams of Fragaria vesca L. (explanations as in Fig. 16) 

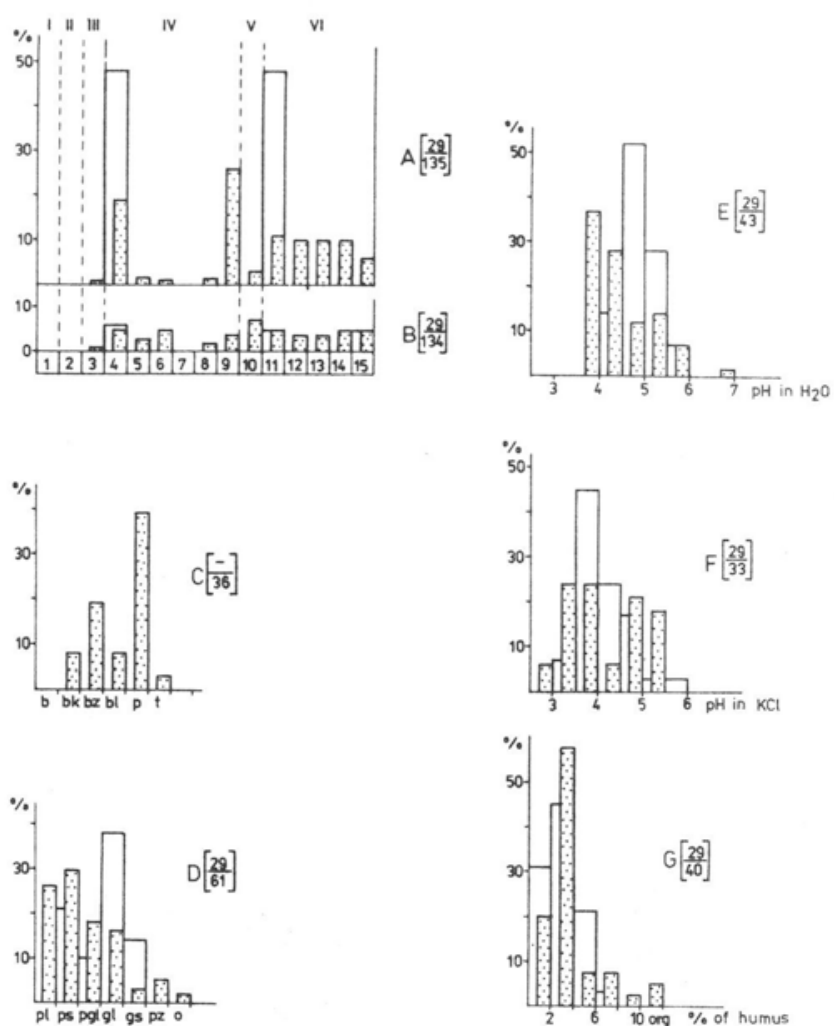
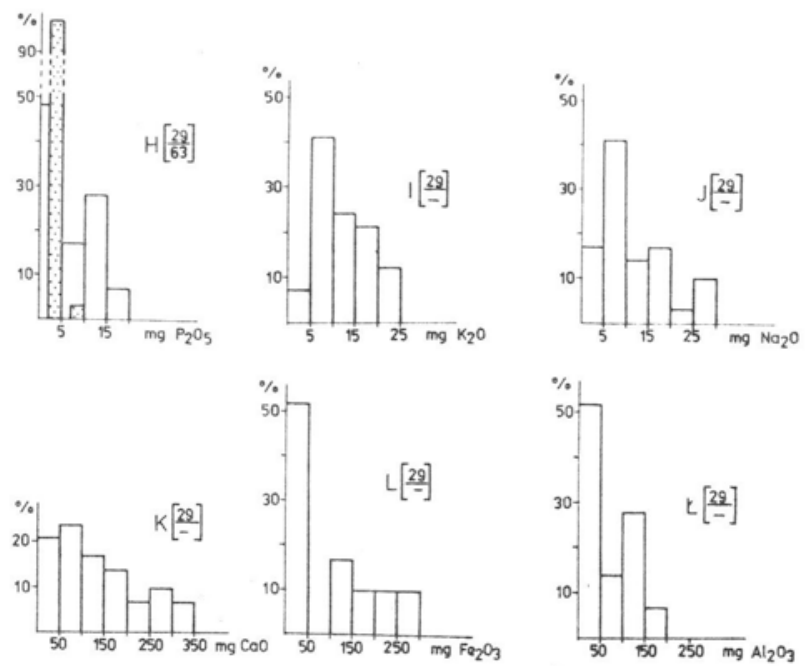

Galium vernum

Scop.
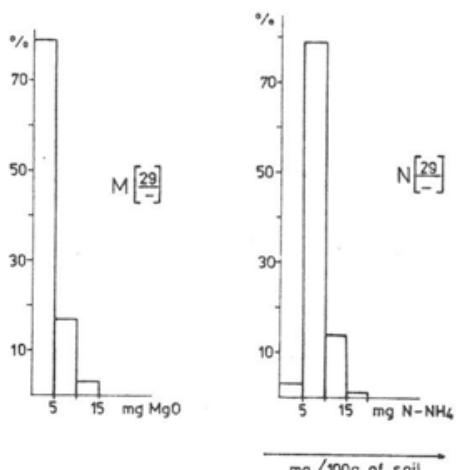

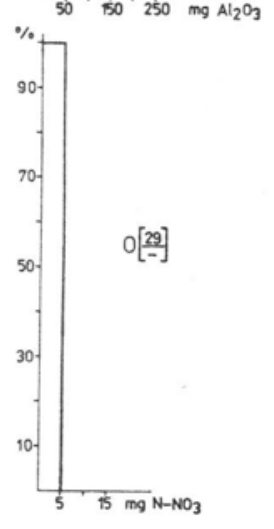

Fig. 22. Ecodiagrams of Galium vernum Scop. (explanations as in Fig. 16) 

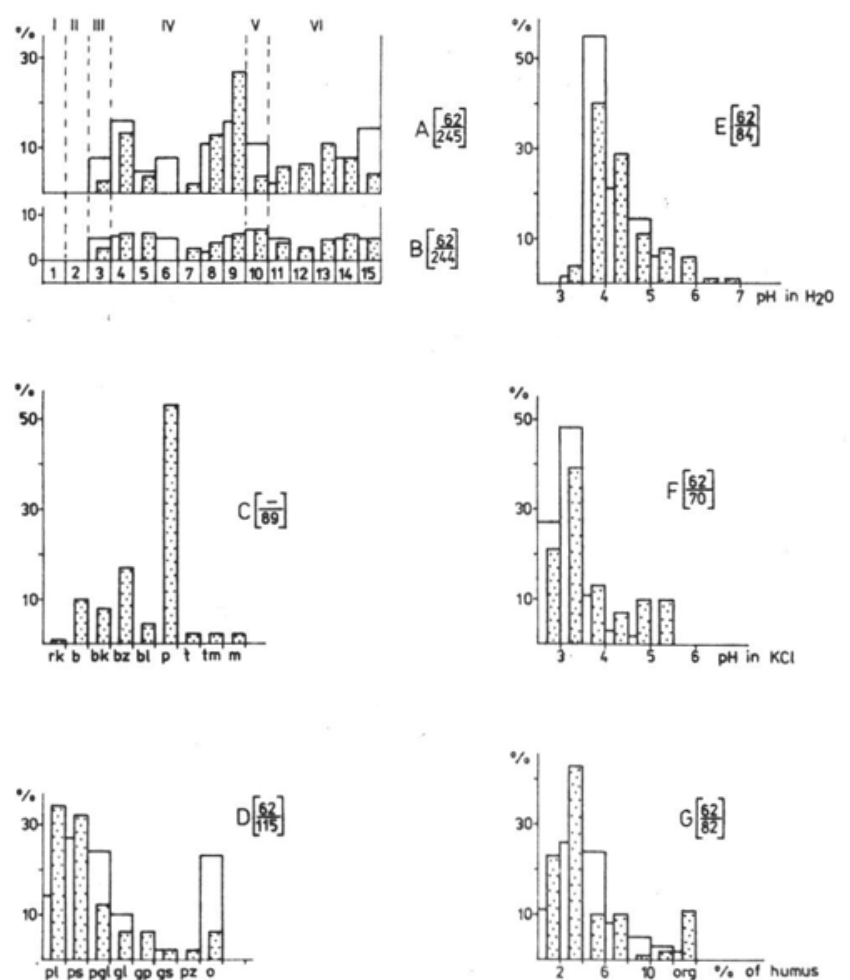
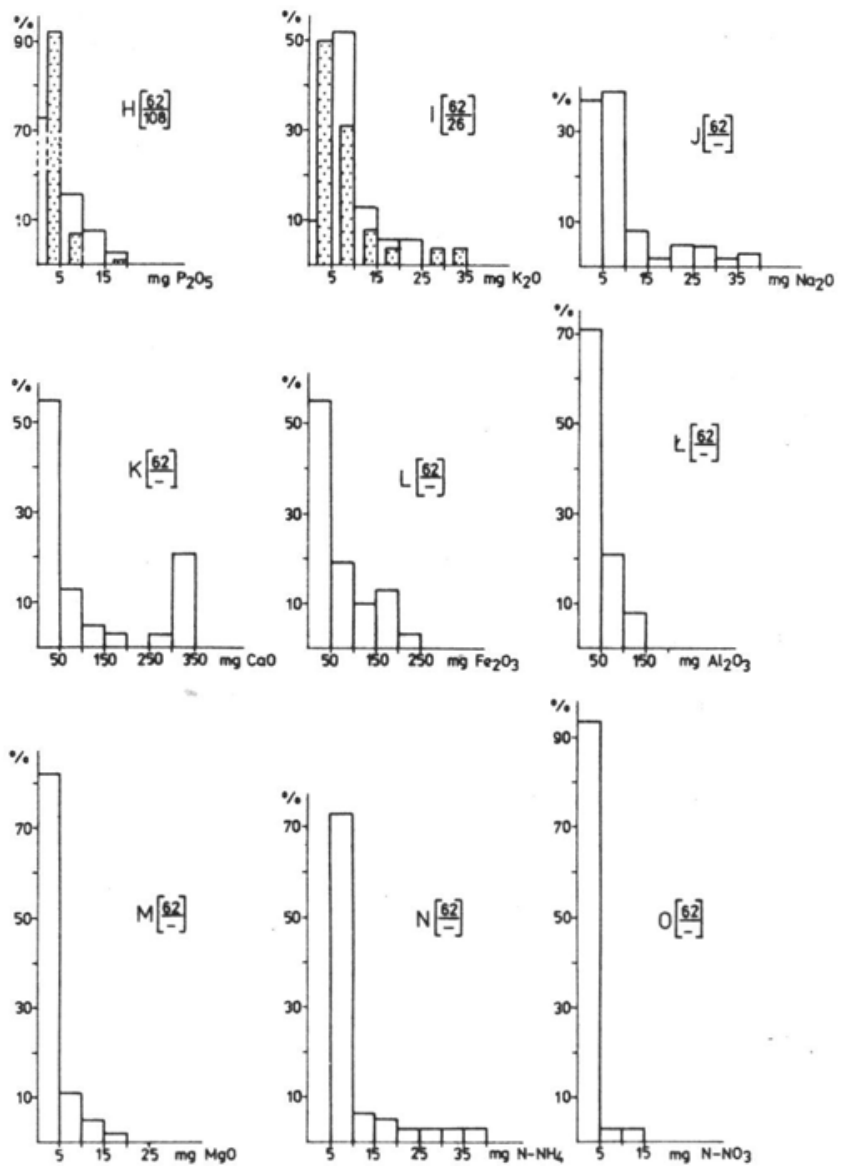

Luzula pilosa /L./Willd.

Fig. 23. Ecodiagrams of Luzula pilosa (L.) Willd. (explanations as in Fig. 16) 

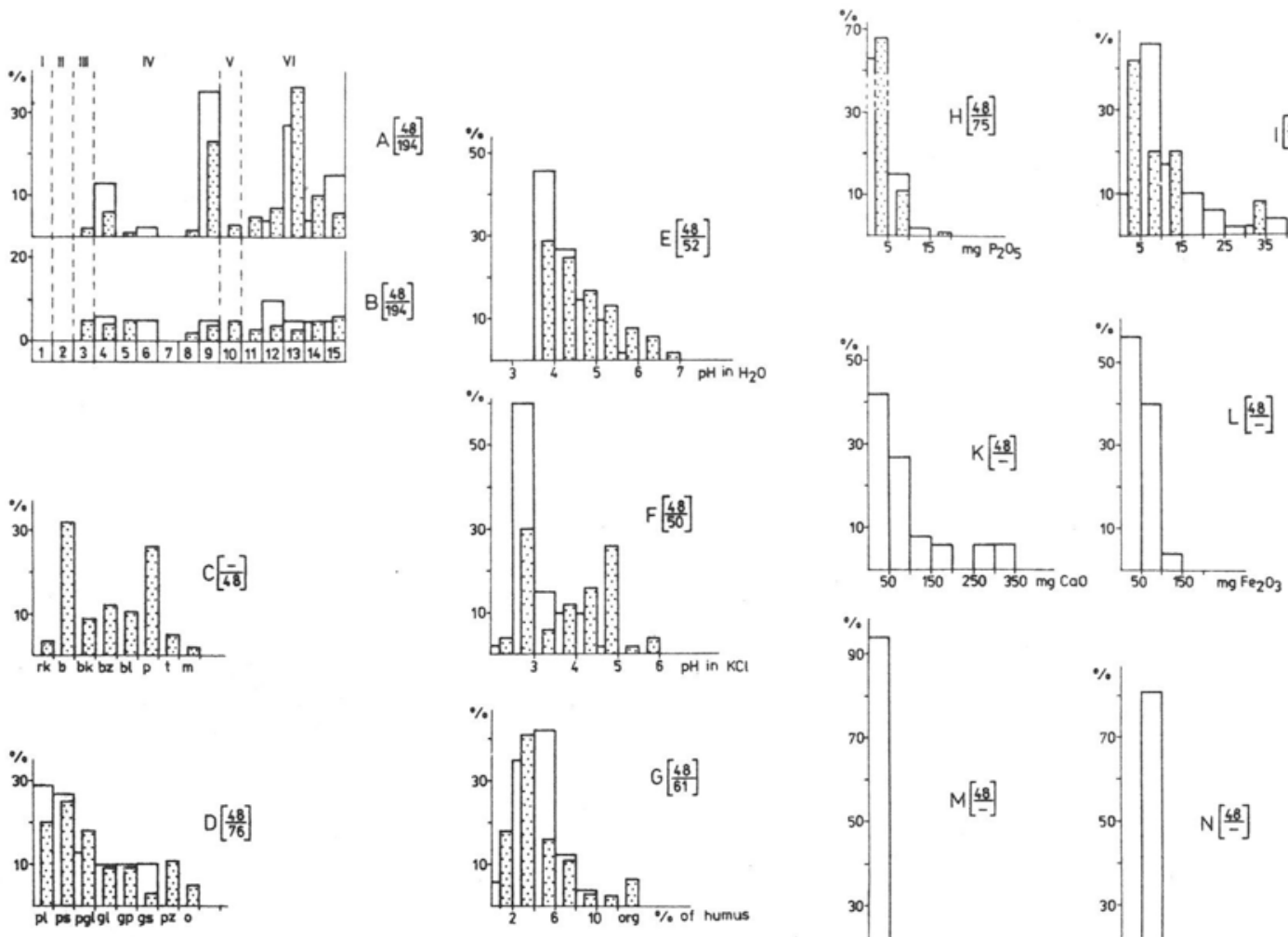

Mycelis muralis /L./ Dum
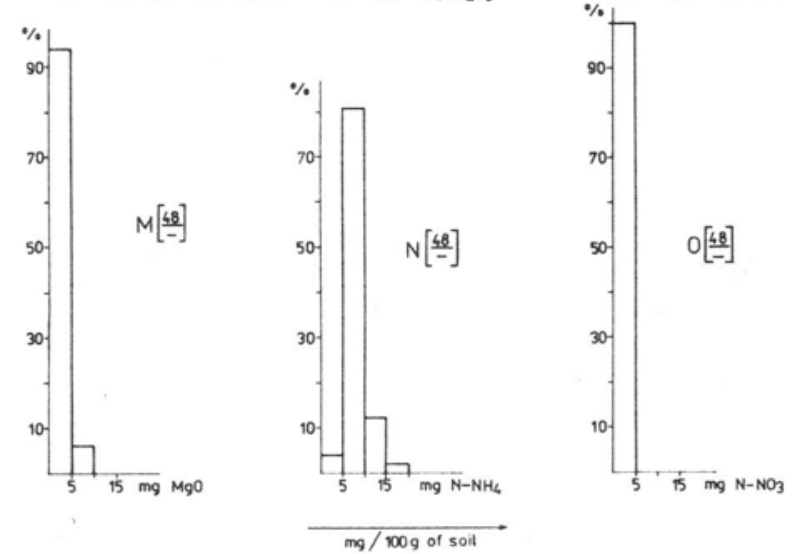

Fig. 24. Ecodiagrams of Mycelis muralis (L.) Dum. (explanations as in Fig. 16) 


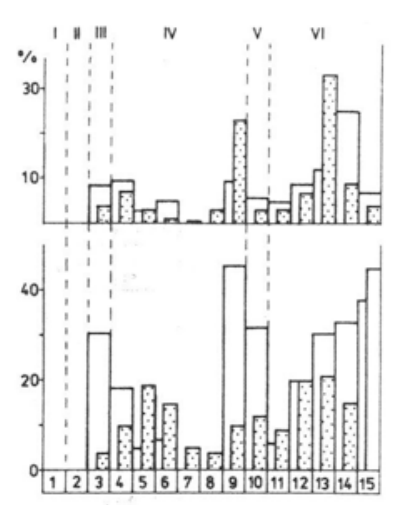

$A\left[\frac{211]}{303}\right]$
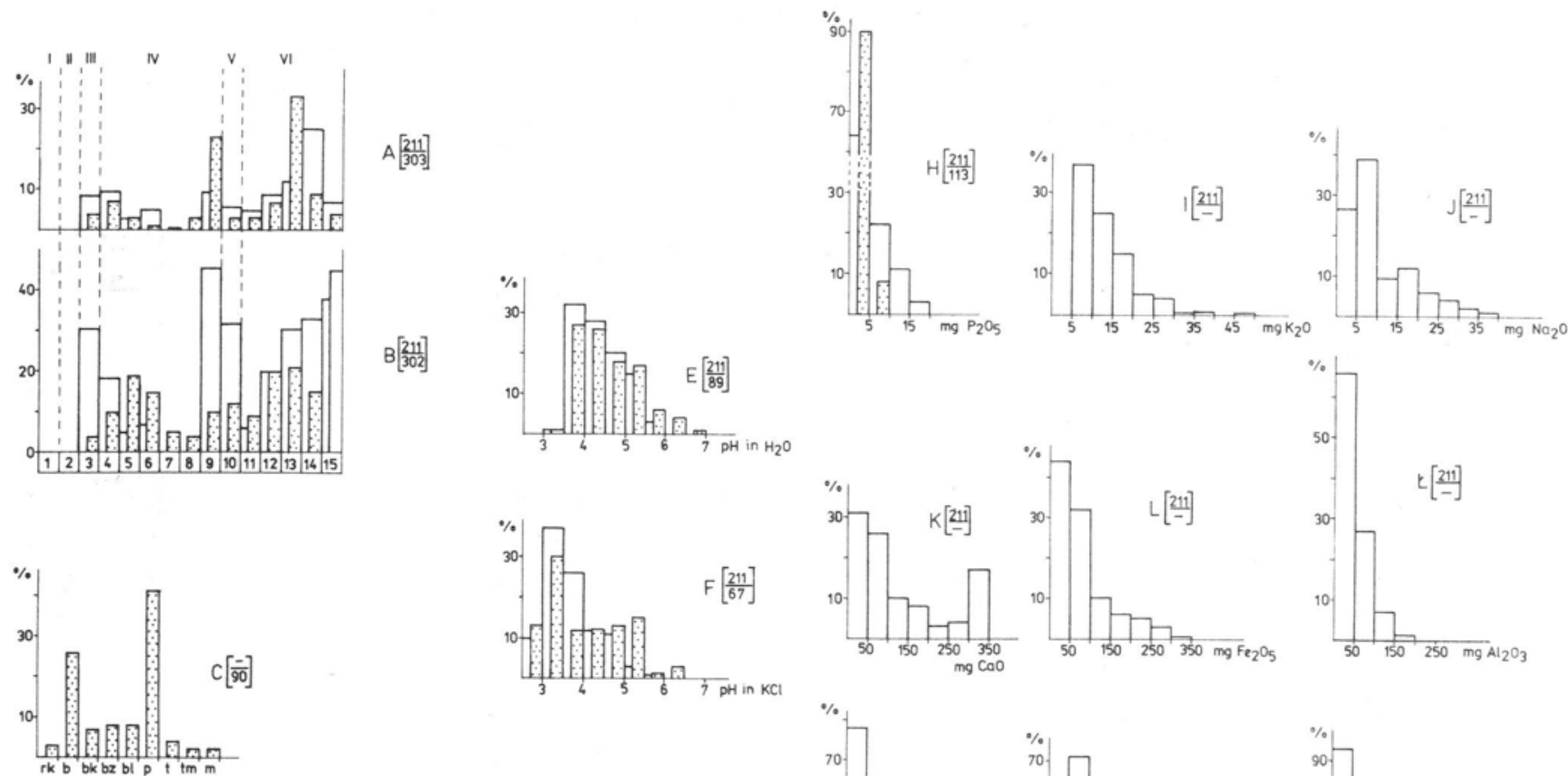

Oxalis acetosella L
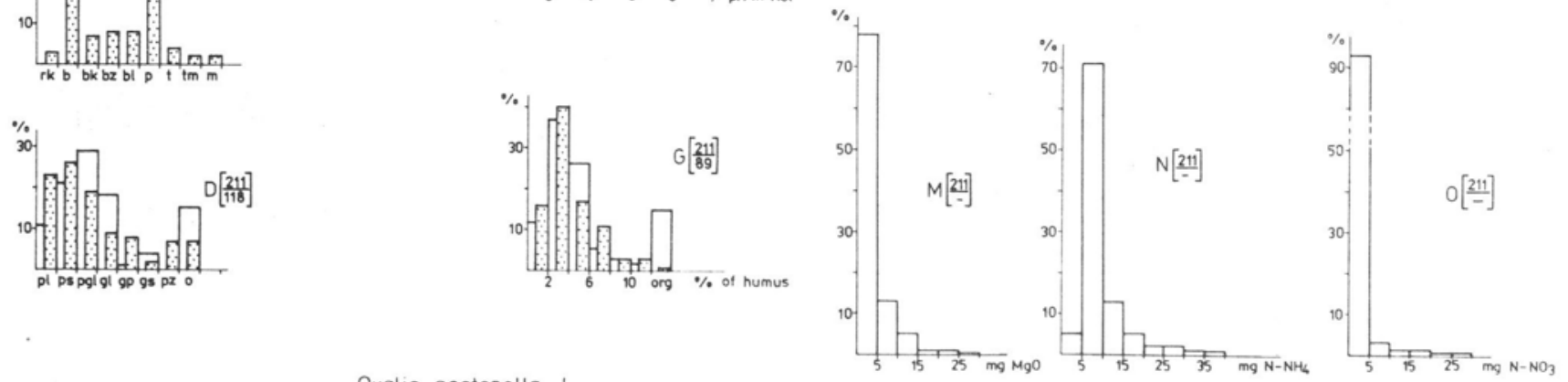

Fig. 25. Ecodiagrams of Oxalis acetosella L. (explanations as in Fig. 16) 
essential for plants (phosphorus, potassium, calcium, magnesium, sodium, iron, aluminium and nitrogen in ammonium and nitrate form) may be classified to meso- and eu-mesotrophic ones. and for Circaea alpina, Geranium robertianum and Milium effusum even to eutrophic ones.

Common forest species connected with communities from the class Vaccinio-Piceetea were taken into account, appearing as a rule in a smaller number of forest communities, mainly in pine and mixed forests, although some appear also sporadically is ecosystems of deciduous character (Figs. 16A. B-20A, B). The accompanying species are found in oak-hornbeam, beech, alder, mixed coniferous and fir communities as well as pine forests (Figs. 21A,B-25A,B). None of these species were found in habitats of highmoor and transitional moor or, as in the case of Fragaria vesca, Galium vernum and Mycelis muralis in bog forest.

Among the soils overgrown with species of the class Vaccinio-Piceetea, as first should be mentioned podsolic soils $(40-70 \%$ of sites of all species), mostly composed of loose sands and coarse sand soils (Figs. 16C,D-20C,D), acidic and strongly acidic (Figs. 16E,F-20E,F).

In the groups of accompanying plants only Luzula pilosa shows a more than 50 per cent frequency of podsolic soils. The remaining species grow on more differentiated soils as regards origin and mechanical composition (Figs. 21C,D-25C,D).

In barely several per cent of soils the $\mathrm{pH}$ values are slightly acidic or neutral. The acidity of the remaining ones does not differ from that noted in soils accompanying plants characteristic for the class Vaccinio-Piceetea (Figs. 21E,F-25E,F).

Both groups of species show no major differences in the humic compound contents of the soil. Most numerous sites with all species belong to the class with humus content from 2 to 4 per cent (Figs. 16G-25G). Three species connected with communities of the class Vaccinio-Piceetea: Trientalis europaea, Vaccinium myrtillus and V. vitis-idaea appear much more frequently than the remaining ones on soils containing in the root horizon poorly decomposed organic matter (Figs. 18G-20G). On these soils Hieracium lachenalii is, however, absent (Fig. 16G).

The poorest habitats in content of essential nutrient components for plants: phosphorus, potassium, sodium, calcium, iron, aluminium, magnesium and nitrogen are occupied by Vaccinium vitis-idaea (Fig. 20H-O). It is found on dry sands extremely poor in the above enumerated elements, although frequently their humus content is not lower than in the remaining soils. These habitats should certainly be considered as oligotrophic.

Hieracium lachenalii (Fig. 16 O), Trientalis europaea (Fig. 18 O) and Vaccinium myrtillus (Fig. 19 O) are also found in habitats in which nitrogen amounts in nitrate form have been recorded in higher than trace amounts.

Among the accompanying species a certain percentage of sites on soils 
with a higher $\mathrm{N}^{-\mathrm{NO}_{3}}$ content show Luzula pilosa (Fig. $23 \mathrm{O}$ ) and Oxalis acetosella (Fig. $25 \mathrm{O}$ ).

The plants of the accompanying group do not differ much from the class Vaccinio-Piceetea ones as regards distribution of sites in dependence on essential macro- and microelements content in the soil.

Habitats of species bound with communities of the class Vaccinio-Piceetea belong to moderately poor, those with Vaccinium vitis-idaea excepted.

Accompanying species with a wider ecological range occur both in oligotrophic and in mesotrophic habitats.

\section{DISCUSSION}

The description of a possibly full ecological spectrum of species on the given area should comprise a number of edaphic factors which are the more important when the biochores of the phytocenoses do not show major differences in the terrain relief, absolute and relative altitude, slope exposure and ecoclimatic differences connected with them.

The ecological amplitudes, for species considered as characteristic for the class Querco-Fagetea or Vaccinio-Piceetea or even lower phytosociological units within these classes (Szafer and Zarzycki 1972. Matuszkiewicz 1981), are as a rule wide, especially as regards such factors as the mechanical soil composition, $\mathrm{pH}$ and humus or organic matter content.

The results obtained for 14 common species of the class Querco-Fagetea are close to the values of the indicator numbers elaborated by Zarzycki (1984), who considers most of them as species of fresh. mineral-humic soils with acid or slightly acid $\mathrm{pH}$, less frequently neutral or alkaline $\mathrm{pH}$. The values of the ecological numbers point to meso- and eutrophic habitats.

For plants bound with ecosystems from the class Vaccinio-Piceetea the present observations also agree with the values of the above mentioned indicator numbers, according to which only Vaccinium vitis-idaea is a species of dry, soils extremely poor or poor in both mineral and organic components. The remaining studied species of this ecological group are considered by Zarzycki (1984) as plants of fresh, moderately poor habitats, for Trientalis europaea and Vaccinium myrtillus - sometimes mesotrophic. The latter two species often are also found on organic soil. Within the area of the Roztocze National Park, Vaccinium vitis-idaea appears also on peat. peaty-mineral and muck-mineral soils.

From among the accompanying species Oxalis acetosella exhibits the widest ecological scale. It is a plant of fresh soils widely differentiated in their trophism - from oligotrophic to eutrophic, and in their acidity - 
from highly acidic to neutral and alkaline. Analysis of the prepared ecodiagrams for this species confirms the values of the indicator numbers (Zarzycki 1984). Under the conditions of the Roztocze ecosystems Oxalis acetosella proved to be a faithful companion of the fir ( $\mathrm{T}$. Kimsa, unpublished data).

Mycelis muralis considered by Zarzycki (1984) as a species characteristic for the class Querco-Fagetea, on the presently studied area shows a strong attachment both to beech and fir forests. Ecological analysis, however, indicates a moderate content in these habitats of mineral and organic components with lack of nitrogen in nitrate form and low $\mathrm{pH}$ values of the soil within the rhizosphere. These data do not allow to treat Mycelis muralis as a species characteristic for the above mentioned class to which communities associated with rich soils and alkaline, neutral or slightly acid $\mathrm{pH}$ are classified (Szafer and Zarzycki 1972).

When analysing the distribution of sites of the particular plant species in dependence on the soil acidity, it is seen that the percentage of occurfence on soils with lower $\mathrm{pH}$ values (especially exchangeable acidity) is higher according to the author's own data than reported in earlier synecological elaborations. The causes of this discrepancy should be sought probably in the date of soil sampling along the transects (between June and July) since forest soils show in this period the lowest $\mathrm{pH}$ values (Musierowicz and Uggla 1964). For this reason it is essential in studies on the ecology of species to apply not only uniform investigation methods, but also the same dates of sampling.

Determination of the amount of readily assimilable phosphorus and of both nitrogen forms in soils overgrown by the here discussed species did not contribute much, in spite of Zarzycki's suggestion (1976b), to the advancement of hypotheses concerning the factors decisive for the distribution of species on the studied area. The great majority of soils under deciduous communities and coniferous forests do not show as a rule essential differences in phosphorus content. Somewhat richer in this component are organic soils, both occupied by plants of the first and second ecological groups. Neither are marked differences observed in the content of other analysed macro- and microelements, the extremely oligotrophic habitats excepted. Forest of the class Vaccinio-Piceetea habitats do not differ by the amount of ammonium nitrogen, but they lack $\mathrm{N}_{-} \mathrm{NO}_{3}$ or show only trace amounts. Sites with several deciduous forest species such as Carex digitata, Hepatica nobilis, Melica nutans and Stellaria holostea in 100 per cent occupy soils deprived of nitrate nitrogen or with barely detectable amounts of it. Species considered as characteristic for the class Vaccinio-Piceetea, however may also be found in habitats containing both forms of nitrogen.

The present results confirm the opinion of Ellenberg (1964) who 
believes that measurement of $\mathrm{NH}_{4}$ and $\mathrm{NH}_{3}$ ions in the soil at a given moment does not indicate its accessibility to plant roots. Owing to the action of soil and weather conditions, total nitrogen content and its particular forms change continuously in time and space. Nitrogen in ammonium form is absorbed by the soil colloids and can be taken up by roots, whereas nitrates are easily washed away by the descending movement of water (Walter 1963). Hence forest of the class Vaccinio-Piceetea habitats with an ombrophilous type of water regime and acidic podsolic soils as well as brown soils exhibit symptoms of podsolisation and easily become deprived of their nitrogen compounds from the rhizosphere. This is, however, no evidence of their lack of nitrogen. but only of the difficult conditions of involvement of this component into the process of matter circulation and energy flow in these forest ecosystems.

\section{REFERENCES}

Chałubińska A.. Wilgat T.. 1959. Podział fiziograficzny woiewództwa lubelskiego. Przewodnik V Ogólnopolskiego Ziazdu PTG. Lublin.

Czarnecka B., 1978. Charakterystyka geobotaniczna rezerwatu leśnego Jarugi na Roztoczu Środkowym. Ann. UMSC. C. 33: 309-331.

Daubenmire R. F.. 1973. Rośliny i środowisko. PWN. Warszawa.

Dobrzański B.. Uziak S.. 1970. Rozpoznawanie i analiza gleb. PWN. Warszawa.

Ellenberg H.. 1964. Stickstoff als Standortsfaktor. Sonderabdruck aus den Berichten der Deutschen Botanischen Gesellschaft 77: 82-92.

Izdebska M.. 1960. Przyczynek do znaıomości flory storczyków lasów nadleśnictwa Kosobudy ze szczególnym uwzględnieniem roślinności rezerwatu obuwika pospolitego $\left(C_{y}\right.$ pripedium calceolus L.). Ann. UMCS. D 15: 421-432.

Izdebska M.. Szynal T.. 1961. Badania geobotaniczne w rezerwacie leśnym Obrocz na Roztoczu Środkowym. Ann. UMCS. B 16:351-386.

Izdebski K. 1959. Badania geobotaniczne w rezerwacie leśnym na Bukowei Górze pod Zwierzyńcem. Ochr. Przyr. 26: 347-367.

Izdebski K.. 1961. Zbiorowiska leśne na Roztoczu Środkowym. Torfowiska. Ann. UMCS. B 16: 303-350.

Izdebski K.. 1962a. Bory na Roztoczu Środkowym. Ann. UMCS C 17: 313-362.

Izdebski K.. 1962b. Grądy na Roztoczu Środkowym. Ekol. pol.. A 10: 523-584.

Izdebski K., 1963. Olsy i bory mieszane na Roztoczu Środkowym. Ann. UMCS C 18: $327-365$.

Izdebski K.. 1964. Charakterystyka geobotaniczna rezerwatu leśnego Czerkies na Roztoczu Środkowym. Ann. UMCS. C 19: 189-233.

Izdebski K.. 1972. Zbiorowiska roślinne proiektowanego rezerwatu leśnego Zwierzyniec. Ann. UMCS. C 27: 206-232.

Izdebski K.. Fiiałkowski D. 1978. Przyrodnicze uzasadnienie poszerzenia granic Roztoczańskiego Parku Narodowego. Folia Soc. Sci. Lubl. B 20: 99-105.

Izdebski K.. Popiołek Z.. 1969. Charakterystyka geobotaniczna proıktowanego rezerwatu leśnego im Z. Czubińskiego na Roztoczu Środkowym. Ann. UMCS C 24: 135-162. Izdebski K. Popiołek 7. 1975. Dynamika zawartość przyswalalnego fosforu i potasu w roślinach i glebie zespołów borowych na Roztoczu Środkowym. Ann. UMCS C 30: 101-112. 
Izdebski K.. Popiołek Z.. 1976. Produkcyiność runa wybranych zbiorowisk borowych na Roztoczu Środkowym. Ann. UMCS. C 31: 55-67.

Kimsa T.. 1974. Badania geobotaniczne wybranych zbiorowisk leśnych na Roztoczu Środkowym metodą transektu pasowego. Ann. UMCS. C 29: 355-363.

Klimaszewski M. (red.). 1972. Geomorfologia Polski, Vol. 1. PWN, Warszawa.

Matuszkiewicz W.. 1981. Przewodnik do oznaczania zbiorowisk roślinnych Polski. PWN,

Warszawa.

Metody analizy chemicznei gleb organicznych i materiałów roślinnych. 1967. IMUZ. Falenty. Michna E.. Warakomski W. 1967/68. O warunkach klimatycznych osady Zwierzyniec. Folia Soc. Sci. Lubl. D 7/8: 83-91.

Musierowicz A.. Uggla H.. 1964. Gleboznawstwo leśne ogólne. PWRiL. Warszawa. Obmiński Z.. 1978. Ekologia lasu. PWN. Warszawa.

Richards B. N.. 1979. Wstęp do ekologii gleby. PWN, Warszawa.

Szafer W.. Kulczyński S. Pawłowski B.. 1969. Rośliny polskie. PWN. Warszawa. Szafer W.. Zarzycki K. (red.). 1972, Szata roślinna Polski, Vol. 1. PWN Warszawa. Szynal T.. 1962. Ogólna analiza florystyczno-ekologiczna zespołów roślinnych nadleśnictwa Kosobudy na Roztoczu Środkowym. Ann. UMCS. C 17: 363-426.

Walter H.. 1963. Uber die Stickstoffausprüche (die Nitrophilie) der Ruderalpflanzen. In: Mitteilungen der Floristisch-soziologischen Arbeitsgemeinschaft 10: 56-69.

Zarzycki K.. 1976a. Ecodiagrams of common vascular plants in the Pieniny Mountains (the Polish West Carpathians). Part I: Ecodiagrams of selected woodland species. Fragm. Flor. Geobot. 22: 479-497.

Zarzycki K.. 1976b. Ecodiagrams of common vascular plants in the Pieniny Mountains (the Polish West Carpathians). Part II: Ecodiagrams of selected grassland species. Fragm. Flor. Geobot. 22: 499-528.

Zarzycki K., 1984. Ekologiczne liczby wskaźnikowe roślin naczyniowych Polski. PAN, Instytut Botaniki. Kraków.

\title{
Ekodiagramy pospolitych gatunków runa leśnego w Roztoczanskim Parku Narodowym
}

\author{
Streszczenie
}

Analiza ekodiagramów wykazała że pospolite gatunki grądowe związane są najsilniej z fitocenozami o charakterze grądowym jak Dentario glandulosae-Fagetum i Tilio-Carpinetum, a także ze zdegradowanymi formami buczyn lub zbiorowiskami ze znacznym udziałem Carpinus betulus w drzewostanie. Mnieiszą frekwencię i stopień pokrycia odnotowano w dąbrowie świetlisteı. borach mieszanych i jodłowych oraz olsie. Badane gatunki roślin nie wykazują w większości przywiązania do określonych rodzaiów i grup mechanicznych gleb. Gleby mineralne są zwykle świeże. organiczne wykazuią większe uwilgotnienie. Odczyn gleb jest naiczęściei kwaśny. znacznie rzadziei zbliżony do oboiętnego. Ze względu na trofizm gleb, wyrażony zawartością próchnicy lub substancii organicznej, jak również istotnych dla roślin makro- i mikroelementów (P. K. Na. Ca. Al, Mg) oraz form azotu. siedliska pospolitych roślin grądowych określono jako mezo- eu-mezo- i eutroficzne. Gatunki borowe (Hieracium lachenalii Gmel. Melampyrum pratense L., Trientalis europaea L. i Vaccinium myrtillus L.) 
zajmują gleby świeże, umiarkowanie ubogie, a nierzadko także mezotroficzne. Jedynie I accinium vitis-idaea $\mathrm{L}$. iest gatunkiem gleb suchych. skraınie ubogich i ubogich w składniki mineralne i organiczne. Grupa gatunków towarzyszących: Fragaria vesca L.. Galium vernum Scop.. Luzula pilosa (L.) Willd. Mycelis muralis (L.) Dum. i Oxalis acetosella L. wykazuie znacznie szerszą skalę ekologiczną. Uzyskane wyniki badań-- podobnie lak w przypadku roślin grądowych - są w zasadzie zgodne z wartościami liczb wskaźnikowych. opracowanych dla roślin naczyniowych Polski przez Zarzyckiego (1984). 